
\title{
JNS Time is spine: a review of translational advances in spinal
cord injury
}

\author{
JNSPG 75th Anniversary Invited Review Article
}

\author{
*Jetan H. Badhiwala, MD, ${ }^{1,2}$ Christopher S. Ahuja, MD, ${ }^{1-3}$ and \\ Michael G. Fehlings, MD, PhD, FRCSC ${ }^{1-3}$
}

\begin{abstract}
1Division of Neurosurgery, Department of Surgery, and ${ }^{2}$ Institute of Medical Science, University of Toronto; and ${ }^{3}$ Department of Genetics and Development, Krembil Research Institute, University Health Network, Toronto, Ontario, Canada

Acute traumatic spinal cord injury $(\mathrm{SCl})$ is a devastating event with far-reaching physical, emotional, and economic consequences for patients, families, and society at large. Timely delivery of specialized care has reduced mortality; however, long-term neurological recovery continues to be limited. In recent years, a number of exciting neuroprotective and regenerative strategies have emerged and have come under active investigation in clinical trials, and several more are coming down the translational pipeline. Among ongoing trials are RISCIS (riluzole), INSPIRE (Neuro-Spinal Scaffold), MASC (minocycline), and SPRING (VX-210). Microstructural MRI techniques have improved our ability to image the injured spinal cord at high resolution. This innovation, combined with serum and cerebrospinal fluid (CSF) analysis, holds the promise of providing a quantitative biomarker readout of spinal cord neural tissue injury, which may improve prognostication and facilitate stratification of patients for enrollment into clinical trials. Given evidence of the effectiveness of early surgical decompression and growing recognition of the concept that "time is spine," infrastructural changes at a systems level are being implemented in many regions around the world to provide a streamlined process for transfer of patients with acute $\mathrm{SCl}$ to a specialized unit. With the continued aging of the population, central cord syndrome is soon expected to become the most common form of acute traumatic $\mathrm{SCl}$; characterization of the pathophysiology, natural history, and optimal treatment of these injuries is hence a key public health priority. Collaborative international efforts have led to the development of clinical practice guidelines for traumatic $\mathrm{SCl}$ based on robust evaluation of current evidence. The current article provides an in-depth review of progress in $\mathrm{SCl}$, covering the above areas.
\end{abstract}

https://thejns.org/doi/abs/10.3171/2018.9.SPINE18682

KEYWORDS spinal cord injury; neuroregeneration; neuroprotection; clinical trial; guideline; stem cell

$\mathrm{T}$ HE physical, financial, and social sequelae of traumatic spinal cord injuries (SCIs) can be devastating for individuals and caregivers alike. ${ }^{27,128}$ The direct lifetime costs of care for over 1 million affected North Americans range from $\$ 1.1$ to $\$ 4.7$ million USD per person. ${ }^{128}$ Timely delivery of specialized care has reduced mortality, but long-term neurological recovery continues to be limited. ${ }^{6-8,64}$ Within the last decade, numerous exciting strategies to protect and regenerate the injured spinal cord have emerged. ${ }^{4,131}$ In this article, we summarize the most promising preclinical and clinical studies, with an emphasis on the underlying pathophysiological mechanisms

\footnotetext{
ABBREVIATIONS aFGF = acidic fibroblast growth factor; AIS = ASIA Impairment Scale; ASIA = American Spinal Injury Association; $A$ UC = area under the curve; bFGF = basic fibroblast growth factor; BSCB = blood-spinal cord barrier; CCS = central cord syndrome; CELLTOP = Adipose Stem Cells for Traumatic Spinal Cord Injury; Cmax = maximum concentration; CNS = central nervous system; CSF = cerebrospinal fluid; CSPG = chondroitin sulfate proteoglycan; CST = corticospinal tract; $\mathrm{DTI}$ = diffusion tensor imaging; ESC = embryonic stem cell; FES = functional electrical stimulation; FIM = Functional Independence Measure; G-CSF = granulocyte colony stimulating factor; GFAP = glial fibrillary acidic protein; GRASSP = Graded Redefined Assessment of Strength Sensibility and Prehension; HAMC = hyaluronan/methylcellulose; HGF = hepatocyte growth factor; IL = interleukin; IV = intravenous; MASC = Minocycline in Acute Spinal Cord Injury; MCP = monocyte chemotactic protein; MPSS = methylprednisolone sodium succinate; MSC = mesenchymal stem cell; MT = magnetization transfer; MTR = MT ratio; NSC = neural stem cell; OEC = olfactory ensheathing cell; OPC = oligodendrocyte progenitor cell; RCT = randomized controlled trial; RISCIS = Riluzole in Acute Spinal Cord Injury Study; SCI = spinal cord injury; SCIM = Spinal Cord Independence Measure; SCING = Spinal Cord Injury Neuroprotection with Glyburide; STASCIS = Surgical Timing in Acute Spinal Cord Injury Study; Tmax = time to Cmax; TNF = tumor necrosis factor.
}

SUBMITTED September 12, 2018. ACCEPTED September 28, 2018.

INCLUDE WHEN CITING DOI: 10.3171/2018.9.SPINE18682.

* J.H.B. and C.S.A. contributed equally to this work. 

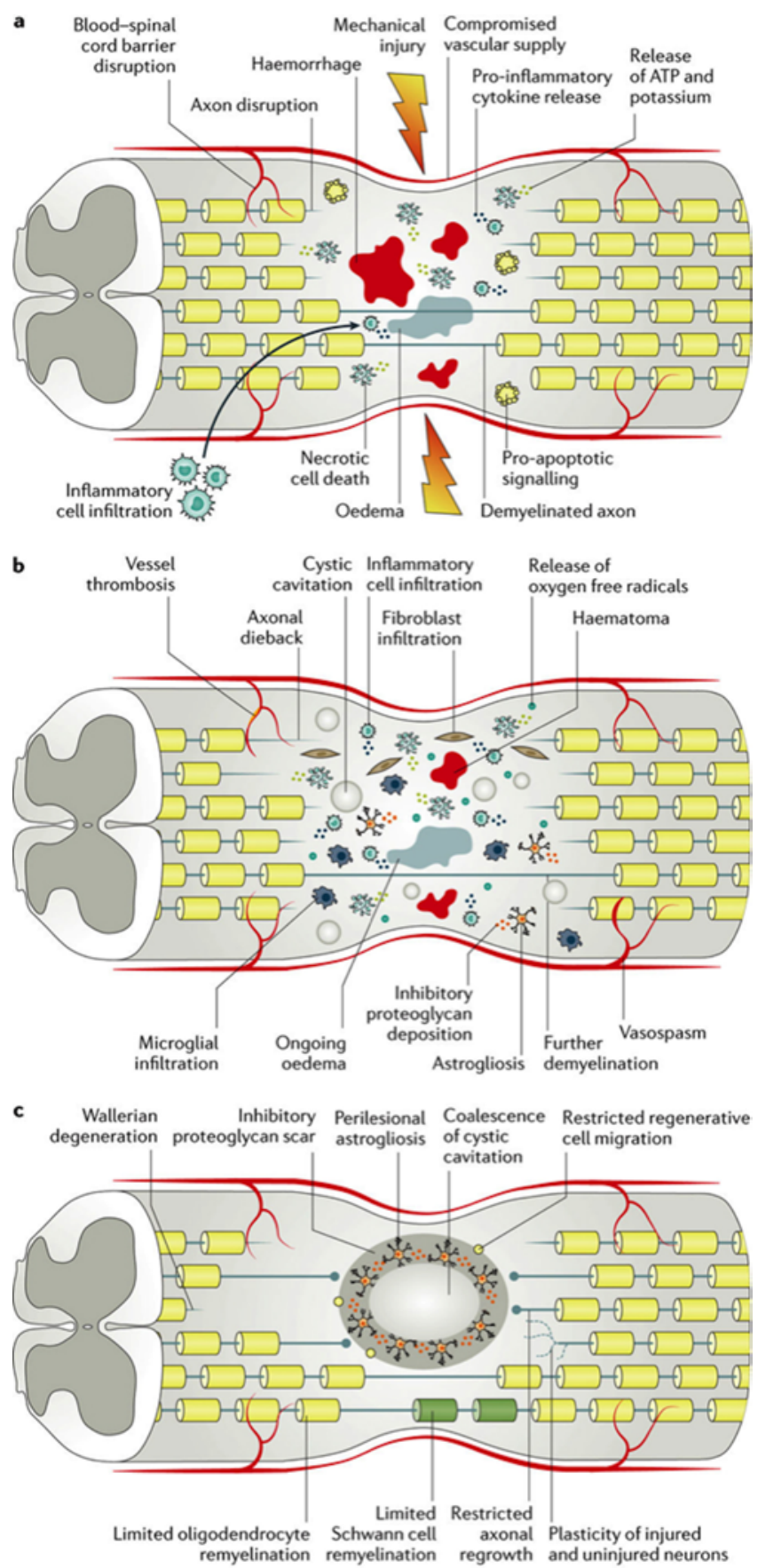

FIG. 1. Pathophysiology of traumatic SCI. "(a) The initial mechanical trauma to the spinal cord initiates a secondary injury cascade that is characterized in the acute phase (that is, $0-48$ hours after injury) by oedema, haemorrhage, ischaemia, inflammatory cell infiltration, the release of cytotoxic products and cell death. This secondary injury leads to necrosis and/or apoptosis of neurons and glial cells, such as oligodendrocytes, which can lead to demyelination and the loss of neural circuits. (b) In the subacute phase (2-4 days after injury), further ischaemia occurs owing to ongoing oedema, vessel thrombosis and vasospasm. Persistent inflammatory cell infiltration causes further cell death, and cystic microcavities form, as cells and the extracellular architecture of the cord are damaged. In addition, astrocytes proliferate and deposit extracellular matrix molecules into the perilesional area.

FIG. 1. (continued) $\rightarrow$
FIG. 1: (c) In the intermediate and chronic phases (2 weeks to 6 months), axons continue to degenerate and the astroglial scar matures to become a potent inhibitor of regeneration. Cystic cavities coalesce to further restrict axonal regrowth and cell migration." Reprinted with permission from Ahuja CS, Wilson JR, Nori S, Kotter MRN, Druschel C, Curt A, Fehlings MG: Traumatic spinal cord injury. Nat Rev Dis Primers $3: 1-21,2017$. @ The authors. Figure is available in color online only.

of action. We also provide a framework for current management approaches based on internationally recognized guidelines and summarize the next frontiers in the field, such as prognostic biomarkers and advanced imaging.

\section{Epidemiology of SCI}

The annual incidence of traumatic SCI varies by region and ranges from 10 to 85 cases per million persons. ${ }^{1,148,154,184}$ Nationally, the highest incidence is reported for New Zealand at 49 cases per million, and the lowest for Spain at 8 cases per million. ${ }^{154}$ There are over 1 million people living with SCI in North America alone, with aggregate direct costs for acute treatment and chronic care in the United States exceeding \$7 billion per year. ${ }^{33,148}$ Given the substantial socioeconomic footprint that it exerts, traumatic SCI is a major public health problem.

The epidemiology of acute traumatic SCI is evolving, as are injury patterns. In particular, the aging population has given rise to an increased proportion of cervical incomplete SCIs, often without spinal column instability, in older persons from low-energy or fall-related mechanisms. ${ }^{34,73,103,164,169}$ Jain et al. ${ }^{73}$ recently performed an epidemiological analysis of traumatic SCI in the United States using data from the National Inpatient Sample, the largest American all-payer inpatient healthcare database. ${ }^{68}$ This analysis revealed that from 1993 to 2012, the mean age of patients suffering an acute SCI increased from 40.5 years to 50.5 years. The incidence of SCI among the younger male population (16-44 years old) steadily declined; meanwhile, there was a steep rise in SCI incidence among males aged 65 to 74 years, from 84 cases per million in 1993 to 131 cases per million in 2012. The proportion of SCI cases that were due to unintentional falls grew from $19.3 \%$ to $40.4 \%$. Similar trends have been reported in much of the developed world, ${ }^{99,154}$ including Canada, ${ }^{28} \mathrm{Ja}-$ pan, ${ }^{158}$ Iceland,,${ }^{86}$ Spain, ${ }^{168}$ and the United Kingdom. ${ }^{120}$ By contrast, the proportion of SCI cases due to land transport is growing in developing countries because of increasing transition to motorized transportation, poor infrastructure, and regulatory challenges. ${ }^{99}$

\section{Pathophysiology of SCI}

Traumatic SCI is characterized by an initial traumatic insult resulting in mechanical damage of neuronal and glial cell membranes, disruption of the microvasculature, ionic dysregulation, and proapoptotic signaling. ${ }^{26,96}$ This initiates a secondary injury cascade that causes further permanent damage and neurological dysfunction. Secondary injury is temporally divided into the acute (within 48 hours), subacute (2-14 days), intermediate (14 days-6 months), and chronic (more than 6 months) phases (Fig. 1).

During the acute phase, hemorrhage and blood-spi- 
nal cord barrier (BSCB) disruption expose the cord to a rapid influx of inflammatory cells (e.g., neutrophils, macrophages, etc.) and cytokines (tumor necrosis factor- $\alpha$ $[$ TNF- $\alpha]$, interleukin-1 $\beta$ [IL-1 $]$ ]). ${ }^{136}$ Necrotic cell death releases ATP, potassium ions, and DNA into the microenvironment, which activates microglia to release additional proinflammatory cytokines and recruit peripheral inflammatory cells. Phagocytes rapidly clear debris, but during the process they generate cytotoxic by-products, such as oxygen and nitrogen free radicals, which produce additional cell injury through protein/lipid oxidation and DNA damage. ${ }^{35,67}$ During the subacute phase, edema progresses, leading to further vascular compromise. Neuron death and reuptake failure by astrocytes cause accumulation of glutamate in the extracellular compartment and excitotoxicity of nearby neurons. ${ }^{114,172}$ Calcium dysregulation, inflammation, and ongoing ischemia cyclically add to the cytotoxic microenvironment. ${ }^{110,111}$

The intermediate and chronic phases of SCI are characterized by dynamic vascular remodeling, alterations in the extracellular matrix composition, and reorganization of local and distal neural circuits. ${ }^{93}$ The substantial cell volume loss leads to ex vacuo formation of cystic microcavitations, which coalesce and become a significant barrier to regeneration, cell migration, and axon regrowth. ${ }^{121,130,159}$ Within the perilesional region, astrocytes proliferate and tightly interweave their extended processes in an attempt to wall off the lesion core. Astrocytes, pericytes, and ependymal cells generate dense deposits of chondroitin sulfate proteoglycans (CSPGs) as part of the fibrous scar, which bind leukocyte common antigen-related receptors, such as protein tyrosine phosphatase $\sigma$ (PTPo). This activates GTPase RhoA and its downstream effector Rho-associated protein kinase (ROCK), leading to axonal growth cone collapse and regenerative failure. ${ }^{20,22,53,123}$

From a systemic perspective, cervical and high thoracic injuries can produce respiratory failure and loss of cardiovascular sympathetic innervation leading to profound hypotension. This can further compound the ischemic insult to the cord. Furthermore, loss of sympathetic innervation to lymphatic organs (e.g., the spleen) can induce a secondary immunodeficiency, termed immune paralysis, which increases patients' susceptibility to infections. ${ }^{18,166}$ Together, these and other pathophysiological mechanisms are the target of neuroprotective, rehabilitative, and neuroregenerative strategies in SCI.

\section{"Time Is Spine"-Early Surgery for SCI}

For many years, the central dogma guiding the treatment of acute ischemic stroke has been "time is brain." In more recent years, there has been growing recognition that the same principle applies to treatment of acute traumatic SCI-that is, "time is spine." This phrase highlights the concept that there is a critical time window after the primary injury to the spinal cord during which secondary injury mechanisms, which cause further neural tissue destruction, may be curtailed. ${ }^{5,146}$ This provides the rationale for early surgery after acute traumatic SCI, which can provide expeditious relief of mechanical compression on the spinal cord and thus attenuate secondary injury cascades and thereby improve outcomes. ${ }^{56}$ The Surgical Timing in Acute Spinal Cord Injury Study (STASCIS) was a prospective, multicenter study that demonstrated that early surgery ( $<24$ hours) resulted in superior neurological recovery at 6 months compared to late surgery ( $\geq 24$ hours) in patients with cervical SCI. ${ }^{48}$ Alongside STASCIS, there has been a growing body of literature favoring early surgical decompression for traumatic SCI.41,45,48,56,75,170,176,177 Likewise, the efficacy of many acute therapies, including methylprednisolone sodium succinate (MPSS) ${ }^{16,17}$ riluzole, ${ }^{40,59}$ minocycline, ${ }^{21}$ and hypothermia, ${ }^{104}$ is time dependent. Further, early optimization of cardiorespiratory and hemodynamic parameters-and management within a specialized acute SCI unit-has been associated with reduced morbidity and mortality as well as improved neurological outcomes. ${ }^{65,107,167}$

Barriers to early surgical intervention for SCI may include lack of operating room availability, transport of patients from the location of injury or from other centers, lack of a specialized operating room nursing team, and lack of surgeon availability on call..$^{57}$ Prior studies in North America and Europe have estimated that only 20\% to $50 \%$ of SCI patients are transferred to an appropriate center and are eligible for surgical decompression within 24 hours of injury. ${ }^{15,57,161}$ The implication is that a substantial proportion of patients arrive at a specialized center outside the critical therapeutic time window and are hence deprived of timely therapy that could potentially translate into improved clinical outcomes. From a research standpoint, transport delays also have implications for clinical trials studying acute-phase therapeutics, as the patients' arrival may fall outside of time-based eligibility criteria. There is hence a need to study and modify healthcare system infrastructure and logistics to permit a streamlined path to a specialized acute care center for patients with an acute SCI.

\section{Central Cord Syndrome-Implications of an Aging Population}

Today, the prototypical SCI is a cervical incomplete injury without fracture or dislocation-e.g., the so-called "central cord syndrome" (CCS) - in an older person who has sustained a fall or low-energy trauma. ${ }^{8}$ In fact, with the continued aging of the population, CCS is expected to soon become the most common form of acute traumatic SCI. ${ }^{44,164}$ The first in-depth description of CCS came from Schneider et al. ${ }^{143}$ in 1954; they detailed a condition involving "disproportionately more motor impairment of the upper than of the lower extremities, bladder dysfunction, usually urinary retention, and varying degrees of sensory loss below the level of the lesion." It has been postulated that CCS is due to a hyperextension mechanism, particularly in the context of a spondylotic or congenitally narrow canal, resulting in injury to the central portion of the spinal cord. ${ }^{66,117,142,144}$ Schneider et al. ${ }^{144}$ proposed that sudden compression of the spinal cord between the hypertrophic spondylotic disc-osteophyte complex and the buckled ligamentum flavum caused a hematomyelic cavity to form within the central gray matter of the spinal cord. He hypothesized that there was disruption of the medi- 
ally placed corticospinal tract (CST) fibers that controlled hand and upper limb function, but relative sparing of the more laterally placed tracts supplying the lower limbs. ${ }^{66,144}$ From a natural history standpoint, patients with CCS have historically demonstrated a relatively favorable profile of neurological recovery, independent of whether early or late surgical management was undertaken. ${ }^{71,141}$

Nonetheless, in considering more recent evidence, it is unclear whether identifying CCS as a unique clinicopathological entity is valid or useful. The original account of the etiology of disproportionate upper limb weakness in CCS was predicated upon the work of Foerster, ${ }^{52}$ who presumed that the lateral CST, like the fasciculi cuneatus and gracilis, had a somatotopic organization. However, Marchi degeneration studies and neuroanatomical tracer techniques in monkeys have confirmed the absence of laminar organization in the CST. ${ }^{29,134}$ In fact, there has not been any neuroanatomical evidence to substantiate the claim of a somatotopic organization of the CST in the spinal cords of humans or higher mammals. ${ }^{74,106,139}$ There is increasing thought that the pattern of predominantly arm and hand weakness seen in CCS has little to do with selective injury to the centrally located regions of the CST and more to do with relative preservation of extrapyramidal fiber tracts. ${ }^{66,74}$ Evidence from transection studies in monkeys indicates that the CST is more important for arm and hand function than for lower-extremity use, and accordingly, any injury to the CST, even diffuse injuries, may produce a syndrome of disproportionately greater arm and hand dysfunction. ${ }^{98,106,147}$ This brings into question the original pathoanatomic basis for CCS. Also, despite previous reports of a comparatively favorable natural history, there is increasing evidence that the pattern of recovery observed in patients with CCS is not substantially different from that of patients with other cervical incomplete SCI syndromes. ${ }^{66,137,171}$ From a treatment perspective, in contrast to the situation with other SCI syndromes, operative intervention for CCS has historically been discouraged out of concern for derailing the potential for natural neurological recovery. However, more recent evidence suggests that early surgical management of patients with CCS is not only safe but also effective, with surgical decompression prior to 24 hours having been shown to result in superior neurological and functional recovery at long-term follow-up..$^{10,102}$

With regard to future work needed in this area, there remains a paucity of published literature elucidating how the pathology, imaging features, clinical course, and surgical outcomes associated with CCS differ from those associated with other cervical injury subtypes. Furthermore, beyond CCS, there has been limited research attempting to identify other unique subgroups of cervical incomplete SCI patients that may demonstrate homogeneous recovery patterns. The clinical course of patients with cervical SCI without fracture or dislocation versus patients with fracture or dislocation is also poorly defined. There is a critical unmet need for high-quality clinical studies investigating cervical incomplete SCI and CCS. Indeed, the devastating physical, emotional, and economic burdens these injuries impose on patients, families, and society at large, taken in the context of an aging population, make this area of research a key public health priority.

\section{Clinical Practice Guidelines}

Clinical practice guidelines for acute traumatic SCI were recently developed and published under the auspices of AOSpine North America, AOSpine International, and the American Association of Neurological Surgeons/Congress of Neurological Surgeons. ${ }^{46}$ Key clinical questions of interest included timing of surgical decompression, use of MPSS, type and timing of anticoagulant thromboprophylaxis, role of baseline MRI in clinical decision making and outcome prediction, and type and timing of rehabilitation. Comprehensive systematic reviews were conducted to synthesize the body of evidence. ${ }^{11,19,49,89,177}$ A multidisciplinary guideline development group then used the results of these reviews, in conjunction with their clinical expertise, to develop clinical practice guideline recommendations ${ }^{39,42,43,45,50}$ in accordance with the methodology proposed by the Grades of Recommendation, Assessment, Development and Evaluation (GRADE) working group. ${ }^{61-63} \mathrm{~A}$ summary of the guideline recommendations is provided in Table 1 .

\section{Key Preclinical Advances and Phase I/II Trials}

\section{Pharmacologics}

SCING-Glyburide

Glibenclamide (also known as glyburide) is a sulfonylurea typically used as an oral diabetes type 2 treatment. In SCI, glibencamide has been shown to block upregulated sulfonylurea receptor 1 (Surl)-regulated nonselective cation channels that may cause persistent post-injury sodium currents. When administered acutely in cervically injured rodents, glibencamide improved 6-week open-field locomotor scores and promoted tissue sparing. ${ }^{153}$ The Spinal Cord Injury Neuroprotection with Glyburide (SCING) trial, a phase I/II study ( $\mathrm{N}=10$; NCT02524379) is now underway, delivering glyburide within 8 hours to patients with American Spinal Injury Association (ASIA) Impairment Scale (AIS) grade $\mathrm{A} / \mathrm{B} / \mathrm{C} \mathrm{C} 2-8$ injuries. The primary outcome is adverse events after drug administration, and the study is expected to conclude in 2020 (Table 2).

\section{Hepatocyte Growth Factor}

Hepatocyte growth factor (HGF) is a c-Met receptor ligand that promotes angiogenesis, mitogenesis, and cell motility in the liver. In models of myocardial infarction and stroke, HGF has been shown to enhance angiogenesis and improve endogenous cell survival. ${ }^{84,85}$ In a preclinical study of SCI in non-human primates, intrathecal HGF was found to enhance ventral motor neuron survival, reduce cavitation at the injury epicenter, and improve motor outcomes. ${ }^{85}$ In a subsequent non-human primate study, HGF was shown to promote angiogenesis after cervical injury resulting in significant improvements in upper limb recovery. ${ }^{84}$ Kringle Pharma Inc. is now recruiting for a phase I/II placebo-controlled study $(\mathrm{N}=48$; NCT02193334) of KP-100IT (intrathecal HGF) in patients with modified Frankel scale A/B1/B2 cervical injuries within 72 hours of injury; 24-week follow-up results are expected in 2019. 


\begin{tabular}{|c|c|c|}
\hline Recommendation & Quality of Evidence & $\begin{array}{l}\text { Strength of } \\
\text { Recommendation }\end{array}$ \\
\hline \multicolumn{3}{|l|}{ Timing of surgical decompression ${ }^{44}$} \\
\hline $\begin{array}{l}\text { We suggest that early surgery ( } \leq 24 \text { hrs after injury) be considered as a treatment option in adult patients } \\
\text { w/ traumatic CCS. }\end{array}$ & Low & Weak \\
\hline We suggest that early surgery be offered as an option for adult acute SCI patients regardless of level. & Low & Weak \\
\hline \multicolumn{3}{|l|}{ Use of MPSS 49} \\
\hline $\begin{array}{l}\text { We suggest not offering a 24-hr infusion of high-dose MPSS to adult patients who present after } 8 \mathrm{hrs} \mathrm{w/} \\
\text { acute SCl. }\end{array}$ & Moderate & Weak \\
\hline $\begin{array}{l}\text { We suggest a 24-hr infusion of high-dose MPSS be offered to adult patients w/in } 8 \text { hrs of acute SCI as a } \\
\text { treatment option. }\end{array}$ & Moderate & Weak \\
\hline We suggest not offering a 48-hr infusion of high-dose MPSS to adult patients w/ acute SCI. & No included studies & Weak \\
\hline \multicolumn{3}{|l|}{ Type \& timing of anticoagulant thromboprophylaxis ${ }^{42}$} \\
\hline $\begin{array}{l}\text { We suggest that anticoagulant thromboprophylaxis be offered routinely to reduce the risk of thromboem- } \\
\text { bolic events in the acute period after SCI. }\end{array}$ & Low & Weak \\
\hline $\begin{array}{l}\text { We suggest that anticoagulant thromboprophylaxis, consisting of either subcutaneous low-molecular- } \\
\text { weight heparin or fixed, low-dose unfractionated heparin, be offered to reduce the risk of thromboembolic } \\
\text { events in the acute period after SCI. Given the potential for increased bleeding events w/ the use of adjusted- } \\
\text { dose unfractionated heparin, we suggest against this treatment option. }\end{array}$ & Low & Weak \\
\hline $\begin{array}{l}\text { We suggest commencing anticoagulant thromboprophylaxis w/in the first } 72 \mathrm{hrs} \text { after injury, if possible, in } \\
\text { order to minimize the risk of venous thromboembolic complications during the period of acute hospitalization. }\end{array}$ & Low & Weak \\
\hline \multicolumn{3}{|l|}{ Role of baseline MRI in clinical decision making \& outcome prediction ${ }^{38}$} \\
\hline $\begin{array}{l}\text { We suggest that MRI be performed in adult patients w/ acute SCI prior to surgical intervention, when } \\
\text { feasible, to facilitate improved clinical decision making. }\end{array}$ & Very low & Weak \\
\hline $\begin{array}{l}\text { We suggest that MRI should be performed in adult patients in the acute period following } \mathrm{SCl} \text {, before or } \\
\text { after surgical intervention, to improve prediction of neurologic outcome. }\end{array}$ & Low & Weak \\
\hline \multicolumn{3}{|l|}{ Type \& timing of rehabilitation ${ }^{43}$} \\
\hline $\begin{array}{l}\text { We suggest that rehabilitation be offered to patients } \mathrm{w} / \text { acute } \mathrm{SCl} \text { when they are medically stable \& can } \\
\text { tolerate required rehabilitation intensity. }\end{array}$ & No included studies & Weak \\
\hline $\begin{array}{l}\text { We suggest offering body weight support treadmill training as an option for ambulation training in addition } \\
\text { to conventional overground walking, dependent on resource availability, context, \& local expertise. }\end{array}$ & Low & Weak \\
\hline $\begin{array}{l}\text { We suggest that individuals w/ acute \& subacute cervical SCI be offered functional electrical therapy as an } \\
\text { option to improve hand \& upper-extremity function. }\end{array}$ & Low & Weak \\
\hline $\begin{array}{l}\text { Based on the absence of any clear benefit, we suggest not offering additional training in unsupported sit- } \\
\text { ting beyond what is currently incorporated in standard rehabilitation. }\end{array}$ & Low & Weak \\
\hline
\end{tabular}

\section{Granulocyte Colony Stimulating Factor}

Granulocyte colony stimulating factor (G-CSF) is a glycoprotein that has demonstrated neuroprotective effects in SCI by enhancing ischemic central nervous system (CNS) cell survival and inhibiting inflammatory cytokine pathways. ${ }^{79}$ This resulted in white matter sparing and improved motor scores in small animal models. A phase I/ IIa $(\mathrm{N}=16)$ trial found that both low- and high-dose regimens of intravenous (IV) G-CSF within 48 hours of injury improved AIS scores without increasing serious adverse events. A double-blind, randomized, placebo-controlled phase III study $(\mathrm{N}=120)$ from Iran of chronic AIS grade $\mathrm{B} / \mathrm{C} / \mathrm{D}$ patients is expected to report in 2018 on 6-month ASIA motor score improvements and Spinal Cord Independence Measure (SCIM) outcomes.

\section{ASCENT-ASCI-Basic Fibroblast Growth Factor}

Basic fibroblast growth factor (bFGF) is a critical pat- terning morphogen during embryonic development that is used to maintain many cell types in a primitive state in vitro, including NSCs. In animal models of SCI, bFGF protects against excitotoxic cell death and can reduce free radical generation. ${ }^{51}$ Daiichi Sankyo Inc. and Asubio Pharmaceuticals Inc. completed the ASCENT-ASCI (Asubio Spinal Cord Early Neuro-recovery Treatment for Acute Spinal Cord Injury), a phase I/II randomized, placebo-controlled study $(\mathrm{N}=62 ; \mathrm{NCT} 01502631)$ of SUN13837, a bFGF analog, in patients with acute C4-7 AIS grade A injuries. While the primary endpoint was not reached, by 16 weeks there were no serious adverse events reported and no significant difference in SCIM outcome score between groups. ${ }^{108}$

\section{Cell Therapies}

Exogenous cell therapies represent an exciting strategy to neuroprotect and regenerate the injured spinal cord 
TABLE 2. Summary of select, ongoing therapeutic phase I/II trials for traumatic SCI

\begin{tabular}{|c|c|c|c|c|c|c|c|}
\hline Trial & Sponsor & $\underset{\mathrm{N}}{\text { Target }}$ & Eligibility Criteria & Intervention & Control & $\begin{array}{l}\text { Primary } \\
\text { Outcome }\end{array}$ & Secondary Outcomes \\
\hline $\begin{array}{l}\text { SCING (gly- } \\
\text { buride) }\end{array}$ & $\begin{array}{l}\text { Ohio State } \\
\text { Univer- } \\
\text { sity }\end{array}$ & 10 & $\begin{array}{l}\text { Age } 18-80 \text { yrs; AIS } \\
\text { grade } A, B \text {, or } C ; \\
\text { neurological level } \\
\text { btwn } C 2 \text { \& C8; able } \\
\text { to receive drug w/in } \\
8 \text { hrs of injury }\end{array}$ & $\begin{array}{l}\text { DiaBeta PO } 1.25 \mathrm{mg} \\
\text { then } 0.625 \mathrm{mg} \mathrm{q} 6 \\
\text { hrs } \times 11 \text { doses }\end{array}$ & None & AEs over $1 \mathrm{yr}$ & None \\
\hline $\begin{array}{r}\text { KP-100IT } \\
(\text { HGF })\end{array}$ & $\begin{array}{l}\text { Kringle } \\
\text { Pharma } \\
\text { Inc. }\end{array}$ & 48 & $\begin{array}{l}\text { Age } 18-75 \text { yrs; modi- } \\
\text { fied Frankel grade A, } \\
\text { B1, or B2; neurologi- } \\
\text { cal level below C3 }\end{array}$ & $\begin{array}{l}\text { HGF intrathecal } 0.6 \\
\text { mg at } 72 \mathrm{hrs} \text {; repeat } \\
\text { wkly } \times 5\end{array}$ & $\begin{array}{l}\text { Placebo at } 72 \text { hrs; } \\
\text { repeat wkly } \times 5\end{array}$ & $\begin{array}{l}\text { AEs over } 24 \\
\text { wks; ASIA } \\
\text { motor score } \\
\text { at } 24 \text { wks }\end{array}$ & $\begin{array}{l}\text { P-100 concentration } \\
\text { in plasma \& CSF at } \\
6 \text { wks; ASIA motor } \\
\text { score at } 12 \text { wks; ASIA } \\
\text { sensory score at } 24 \\
\text { wks; modified Frankel } \\
\text { scale at } 24 \text { wks }\end{array}$ \\
\hline G-CSF & $\begin{array}{l}\text { Tehran Uni- } \\
\text { versity of } \\
\text { Medical } \\
\text { Sciences }\end{array}$ & 120 & $\begin{array}{l}\text { Age } 18-60 \text { yrs; AIS } \\
\text { grade } B, C \text {, or } D ; \\
\text { injury more than } 6 \\
\text { mos prior }\end{array}$ & $\begin{array}{l}\text { G-CSF } 300 \text { mg once } \\
\text { daily } \times 7 \text { days }\end{array}$ & $\begin{array}{l}\text { Normal saline } \times 7 \\
\quad \text { days }\end{array}$ & $\begin{array}{l}\text { ASIA motor } \\
\text { \& sensory } \\
\text { scores at } 6 \\
\text { mos }\end{array}$ & $\begin{array}{l}\text { SCIM-III \& IANR- } \\
\text { SCIFRS at } 6 \text { mos; } \\
\text { AEs up to } 1 \mathrm{yr}\end{array}$ \\
\hline $\begin{array}{l}\text { CSF Drain- } \\
\text { age in } \\
\text { Acute } \\
\text { SCl }\end{array}$ & $\begin{array}{l}\text { St. Joseph's } \\
\text { Hospital } \\
\text { and } \\
\text { Medical } \\
\text { Center }\end{array}$ & 60 & $\begin{array}{l}\text { Age } 18-75 \text { yrs; AIS } \\
\text { grade A, B, or } \\
\text { C; neurological } \\
\text { level btwn C4 \& C8; } \\
\text { injury less than } 24 \\
\text { hrs prior }\end{array}$ & $\begin{array}{l}\text { CSF drainage by } \\
\text { lumbar drain (target } \\
\text { ITP } 10 \mathrm{~mm} \mathrm{Hg} \text { ) \& } \\
\text { elevation of MAP } \\
\text { (target MAP } 100-110 \\
\text { mm Hg) } \times 5 \text { days }\end{array}$ & $\begin{array}{l}\text { Lumbar drain w/o } \\
\text { CSF drainage } \\
\& \text { maintenance } \\
\text { of MAP (target } \\
\text { MAP } 85-90 \mathrm{~mm} \\
\mathrm{Hg}) \times 5 \text { days }\end{array}$ & $\begin{array}{l}\text { Intrathecal } \\
\text { pressure at } \\
5 \text { days; ASIA } \\
\text { motor score } \\
\text { at } 180 \text { days }\end{array}$ & $\begin{array}{l}\text { AIS grade at } 180 \text { days; } \\
\text { ASIA sensory score } \\
\text { at } 180 \text { days; SCIM } \\
\text { at } 180 \text { days; pain } \\
\text { numeric rating scale } \\
\text { at } 180 \text { days }\end{array}$ \\
\hline AST-OPC1 & $\begin{array}{l}\text { Asterias } \\
\text { Biothera- } \\
\text { peutics } \\
\text { Inc. }\end{array}$ & 35 & $\begin{array}{l}\text { Age } 18-69 \text { yrs; AIS } \\
\text { grade A or B; neuro- } \\
\text { logical level btwn C4 } \\
\text { \& C7; able to receive } \\
\text { cells btwn } 21 \& 42 \\
\text { days after SCl }\end{array}$ & $\begin{array}{l}\text { AST-OPC1s-dose } \\
\text { escalation across } \\
\text { patients w/ } 2,10 \text {, or } \\
20 \text { million cells }\end{array}$ & None & AEs over 1 yr & $\begin{array}{l}\text { Upper-extremity } \\
\text { ISNCSCI motor score } \\
\text { at } 1 \mathrm{yr}\end{array}$ \\
\hline NSI-566 & $\begin{array}{l}\text { Neuralstem } \\
\text { Inc. }\end{array}$ & 8 & $\begin{array}{l}\text { Age } 18-65 \text { yrs; AIS } \\
\text { grade A; neurologi- } \\
\text { cal level btwn C5 \& } \\
\text { C7 or T2 \& T12; able } \\
\text { to receive cells btwn } \\
1 \& 2 \text { yrs after SCl }\end{array}$ & $\begin{array}{l}\text { Human spinal cord-de- } \\
\text { rived NSC (NSI-566) } \\
\text { transplant }\end{array}$ & None & $\begin{array}{l}\text { AEs over } 6 \\
\text { mos }\end{array}$ & $\begin{array}{c}\text { Graft survival on MRI \& } \\
\text { potential autopsy at } \\
60 \text { mos; EMG, SCIM, } \\
\text { ISNCSCl at } 60 \text { mos }\end{array}$ \\
\hline $\begin{array}{l}\text { Safety of } \\
\text { ahSC in } \\
\text { Chronic } \\
\text { SCl }\end{array}$ & $\begin{array}{l}\text { The Miami } \\
\text { Project } \\
\text { to Cure } \\
\text { Paraysis }\end{array}$ & 10 & $\begin{array}{l}\text { Age } 18-65 \text { yrs; AIS } \\
\text { grade A, B, or C; } \\
\text { neurological level } \\
\text { btwn C5 \& T12; at } \\
\text { least } 1 \text { yr since } \\
\text { injury }\end{array}$ & $\begin{array}{l}\text { Autologous human } \\
\text { sural nerve Schwann } \\
\text { cell transplant }\end{array}$ & None & $\begin{array}{l}\text { ISNCSCI at } 6 \\
\text { mos; MRI at } \\
6 \text { mos; neu- } \\
\text { ropathic pain } \\
\text { inventory at } \\
6 \text { mos }\end{array}$ & $\begin{array}{l}\text { SCIM-III, SCI-functional } \\
\text { index computer adap- } \\
\text { tive testing, walk test, } \\
\text { MEP, SSEP, \& others } \\
\text { at } 6 \text { mos }\end{array}$ \\
\hline $\begin{array}{l}\text { CELLTOP } \\
\text { (adipose } \\
\text { stem } \\
\text { cells for } \\
\text { SCI) }\end{array}$ & Allan Dietz & 10 & $\begin{array}{c}\text { Age }>18 \text { yrs; AIS grade } \\
\text { A or B; SCl btwn } 2 \\
\text { wks \& } 1 \text { yr prior }\end{array}$ & $\begin{array}{l}100 \text { million intrathecal } \\
\text { autologous, adipose- } \\
\text { derived MSCs }\end{array}$ & None & AEs over 4 wks & $\begin{array}{l}\text { CBC, CRP, Cr, BUN, \& } \\
\text { blood electrolytes at } \\
4 \text { wks; AEs over } 48 \\
\text { wks; AIS grade at } 96 \\
\text { wks; SSEP \& MEP at } \\
96 \text { wks }\end{array}$ \\
\hline $\begin{array}{l}\text { Stem Cell } \\
\text { Therapy } \\
\text { in } \mathrm{SCl}\end{array}$ & $\begin{array}{l}\text { Neurogen } \\
\text { Brain and } \\
\text { Spine } \\
\text { Institute }\end{array}$ & 500 & Age 1-65 yrs & $\begin{array}{l}\text { Intrathecal autolo- } \\
\text { gous bone marrow } \\
\text { mononuclear cell } \\
\text { transplant }\end{array}$ & No intervention & $\begin{array}{l}\text { Clinical symp- } \\
\text { toms at } 6 \\
\text { mos }\end{array}$ & FIM at 6 mos \\
\hline
\end{tabular}

$\mathrm{AE}$ = adverse event; ahSC = adult human Schwann cells; $\mathrm{BUN}=$ blood urea nitrogen; $\mathrm{CBC}=$ complete blood count; $\mathrm{Cr}=$ creatinine; $\mathrm{CRP}=\mathrm{C}$-reactive protein; $\mathrm{EMG}=$ electromyography; IANR-SCIFRS = International Association of Neurorestoratology Spinal Cord Injury Functional Rating Scale; ISNCSCI = International Standards for Neurological Classification of Spinal Cord Injury; ITP = intrathecal pressure; MAP = mean arterial pressure; MEP = motor evoked potential testing; $P O=$ by mouth; $q=$ every; SSEP = somatosensory evoked potential testing. 
through mechanisms such as paracrine signaling, immune modulation, extracellular matrix deposition, induction of plasticity, and direct neuroglial cell replacement. ${ }^{12}$ As living and reactive therapies, the actions of these treatments are dependent on the specific cell type, route of administration (IV, intrathecal, intraparenchymal), cell state, and timing of delivery. ${ }^{82,126,129}$

Mesenchymal stem cells (MSCs), olfactory ensheathing cells (OECs), and Schwann cells can be harvested from allogenic sources to produce standardized stocks or can be autologously derived to reduce the risk of post-transplant rejection. Neural stem cells (NSCs) and oligodendrocyte progenitor cells (OPCs) are more challenging to isolate in large numbers from adult allogenic sources. Typically these cells are derived from pluripotent stem cells such as embryonic stem cells (ESCs) or induced pluripotent stem cells (iPSCs). ${ }^{12,81}$ While both cell types can proliferate and generate cells of all 3 germ layers, iPSCs avoid the ethical issues surrounding the use of embryonic tissue. More recently, technology has emerged to directly reprogram somatic cells into $\mathrm{NSCs}^{127}$ and $\mathrm{MSCs}^{23}$ without an interceding pluripotent stage.

\section{Mesenchymal Stem Cells}

MSCs are rapidly proliferating, multipotent connective tissue progenitor cells capable of differentiating into myocytes, chondrocytes, adipocytes, and osteoblasts. ${ }^{51,97}$ MSCs are readily found throughout the body and can be harvested from accessible tissue such as bone marrow, abdominal fat, and skeletal muscle. ${ }^{31,149}$ MSCs are currently under study for their immunomodulatory properties in multiple sclerosis, ${ }^{37}$ sepsis, ${ }^{94}$ and arthritis. ${ }^{185}$ In preclinical SCI studies, MSCs have demonstrated the ability to enhance tissue sparing and functional recovery through immunomodulation, neurotrophic factor secretion, and pro-angiogenic signaling. ${ }^{5,8,56} \mathrm{MSCs}$ derived from various sources are being assessed in multiple ongoing clinical trials.

Pharmicell Co. is assessing bone marrow-derived MSCs in a phase II/III trial ( $\mathrm{N}=32$; NCT01676441). Patients with chronic cervical AIS grade $\mathrm{B}$ injuries are receiving $3.2 \times 10^{7}$ intrathecal MSCs and $1.6 \times 10^{7}$ intraparenchymal MSCs. Outcomes include ASIA motor scores, MR-based diffusion tensor imaging (DTI), and electrophysiological tests; results are expected in 2020.

Adipose-derived MSCs are being assessed at the Mayo Clinic in the Adipose Stem Cells for Traumatic Spinal Cord Injury (CELLTOP) study, a phase I trial $(\mathrm{N}=10$; NCT03308565) delivering $1 \times 10^{8}$ autologous MSCs into the cerebrospinal fluid (CSF) of patients with 2-week- to 1 -year-old AIS grade $\mathrm{A} / \mathrm{B} / \mathrm{C}$ injuries. Results are expected in 2023. Umbilical cord-derived MSCs are also being tested in multiple recently registered phase I/II trials (NCT03521323; NCT03505034; NCT02481440) for both subacute and chronic injury.

\section{Olfactory Ensheathing Cells}

OECs are highly phagocytic cells that surround olfactory neurons and rapidly clear pathogens and debris at the CNS-nasal mucosa border. ${ }^{38,152,178,188}$ They also generate a favorable environment by expressing neurotrophins and facilitating olfactory regeneration after injury. ${ }^{9} \mathrm{OECs}$ have been harvested from the olfactory bulb and the nasal mucosa for transplant into the cord. ${ }^{112}$ In SCI models, they enhance neuron and glial cell survival in the early phases, promote remyelination, and reduce neuroinflammation. ${ }^{113,140,173}$ Numerous clinical trials have been completed demonstrating the safety and feasibility of OEC transplants for SCI. A meta-analysis of 1193 cases across several clinical trials found no increase in serious adverse events; however, efficacy could not be determined due to methodological and technical concerns. ${ }^{109}$

\section{Schwann Cells}

Schwann cells provide structural scaffolding and promote a favorable microenvironment to facilitate the robust regeneration observed in the peripheral nervous system. In preclinical SCI studies, intraparenchymal and intrathecal Schwann cell transplants have been shown to reduce cystic cavitation, enhance tissue sparing, and promote remyelination, resulting in sensory and motor recovery. ${ }^{14,70,76,155,175}$

The Miami Project to Cure Paralysis completed a phase I ( $\mathrm{N}=6$; NCT01739023), nonrandomized, dose-escalation study of autologous intraparenchymal Schwann cell therapy in individuals with subacute-intermediate AIS grade A T3-11 injuries. At 1 year's follow-up, no serious complications were reported. The same group is currently recruiting for a phase I ( $\mathrm{N}=10$; NCT02354625), open-label, nonrandomized trial of autologous MSCs in patients with AIS grade $\mathrm{A} / \mathrm{B} / \mathrm{C}$ injuries occurring at least 12 months prior to enrollment. Results are expected by 2019 .

\section{Neural Stem Cells}

NSCs are self-renewing, multipotent progenitor cells capable of differentiating to neural cells, oligodendrocytes, and astrocytes. ${ }^{83}$ Although they populate the central nervous system (CNS) during fetal development, in adults they are found in limited regions such as the subventricular zone and around the central canal of the spinal cord. ${ }^{58,124,133}$ NSCs derived from primary and reprogrammed autologous, allogeneic, and xenogeneic sources have demonstrated efficacy in small and large animal models of SCI. ${ }^{12,78,135,157}$ A recent meta-analysis of 74 preclinical studies found significant motor recovery (pooled SMD [standardized mean difference] 1.45; $\mathrm{p}<0.001$ ) after NSC transplant. ${ }^{186}$ While multiple mechanisms of action likely exist, studies suggest that NSCs enhance neurotrophic signaling, promote remodeling of neural circuitry, improve remyelination, and modify the extracellular matrix.

Two phase II trials in cervical ( $\mathrm{N}=31$; NCT02163876) and thoracic ( $\mathrm{N}=12$; NCT01321333) SCI led by Stem Cells Inc. transplanted human fetal brain-derived CNS stem cells. The trials were terminated early in 2016; according to a recent report, there was no significant increase in the rate of serious adverse events with escalating doses, suggesting that the therapy was well tolerated. ${ }^{105}$ Neuralstem Inc. is now recruiting for an open-label, single-site phase I ( $\mathrm{N}=8$; NCT01772810) safety study of human spinal cord-derived NSCs in individuals with 1- to 2-yearold AIS grade A injuries at C5-7 or T2-12. Results are expected in 2022. 


\section{Oligodendrocyte Progenitor Cells}

OPCs are self-renewing, multipotent cells that most commonly differentiate into oligodendrocytes. They secrete neurotrophic factors, and their oligodendroglial progeny are capable of remyelinating denuded axons after SCI in animals, resulting in tissue sparing and neurobehavioral recovery. ${ }^{80,150}$

Asterias Biotherapeutics Inc. is assessing AST-OPC1, human ESC-derived OPCs, as part of a phase I/IIa (N = 35; NCT02302157) dose-escalation study. Between 21 and 42 days after SCI, patients with AIS grade A/B/C4-7 injuries will receive $2 \times 10^{6}, 10 \times 10^{6}$, or $20 \times 10^{6}$ AST-OPC1s. Patients will be assessed for 1 year, with results expected at the end of 2018.

\section{Biomaterials}

Biomaterials represent an emerging strategy to enhance recovery after SCI by acting as a structural scaffold for endogenous regeneration, providing directional guidance cues, delivering drugs locally, and supporting the survival of transplanted cells. Numerous materials are demonstrating promising results in clinically relevant animal models.

\section{QL6}

QL6 is a biodegradable, neutral-pH, peptide biomaterial that is water soluble and self-assembles into a nanometerscale lattice-like conformation in vivo. QL6 demonstrates a neuroprotective effect in SCI and can be delivered prior to or with NSCs to enhance graft survival, reduce inflammation and glial scarring, and improve motor function in small animal models. ${ }^{72,115,189}$

\section{Hyaluronan/Methylcellulose}

Hyaluronan/methylcellulose (HAMC) is an injectable, biodegradable polymer blend ${ }^{60}$ that is capable of supporting the engraftment of NSCs ${ }^{125}$ and OPCs ${ }^{54}$ in SCI to enhance functional recovery. The polymer can also be modified to deliver growth factors (e.g., PDGF-AA [plateletderived growth factor AA]), ${ }^{125}$ small peptide ligands (e.g., RGD), ${ }^{54}$ and CSPG scar-degrading drugs (e.g., chondroitinase $A B C)^{132}$ using affinity release.

\section{INSPIRE-Neuro-Spinal Scaffold}

The Neuro-Spinal Scaffold (InVivo Therapeutics Corp.) is a porous bioresorbable polymer scaffold that promotes appositional healing, spares white matter, decreases posttraumatic cyst formation, and normalizes intraparenchymal tissue pressure. ${ }^{163}$ The polymer is composed of poly(lacticco-glycolic acid) covalently conjugated to poly-L-lysine and is designed to facilitate favorable cell-material interactions. Polymer scaffold seeded with neural stem cells has been shown to improve functional recovery in animal hemisection models. ${ }^{138,162}$

A pilot study evaluating the safety and feasibility of implantation of the Neuro-Spinal Scaffold (InVivo Study of Probable Benefit of the Neuro-Spinal Scaffold ${ }^{\mathrm{TM}}$ for Safety and Neurologic Recovery in Subjects with Complete Thoracic AIS A Spinal Cord Injury) has completed recruitment and is currently in the follow-up phase (NCT02138110). Eligibility criteria included age 16 to 70 years; AIS A trau- matic SCI with a neurological level between T2 and T12/ L1; ability to receive the scaffold within 96 hours of injury; and non-penetrating contusion injury no less than 4-mm diameter as determined by MRI. A case report of the first patient to undergo implantation of the scaffold as part of this trial has been published previously. ${ }^{163}$ The patient was a 25-year-old man with a T11-12 fracture-dislocation sustained in a motocross accident resulting in a T11 AIS A SCI. A $2 \times 10-\mathrm{mm}$ scaffold was implanted directly into the traumatic cavity within the spinal cord parenchyma at T12 through a dorsal root entry zone myelotomy. At 3 months, neurological function had improved to an L1 AIS $\mathrm{C}$ incomplete injury. No procedural complication or safety concern resulting from implantation of the scaffold was seen at 6 months' follow-up.

\section{Key Phase III Trials}

A number of phase III randomized controlled trials (RCTs) testing the safety and efficacy of neuroprotective and regenerative therapies for acute traumatic SCI are currently underway (Table 3).

\section{RISCIS-Riluzole}

Riluzole is a sodium channel-blocking benzothiazole anticonvulsant drug. Riluzole modulates excitatory neurotransmission and has been shown to improve survival in the setting of amyotrophic lateral sclerosis (ALS). ${ }^{122}$ The drug is currently approved for use in ALS by regulatory authorities in several countries. ${ }^{122}$ Its well-defined human safety record makes riluzole an attractive agent for translation into clinical trials of SCI treatment. With regard to mechanism of action, during the secondary injury cascade of SCI, there is thrombosis and vasospasm of the spinal cord microvasculature, leading to ischemia. This triggers neuronal membrane dysfunction, with increased $\mathrm{Na}^{+}$influx from continuous activation of voltage-gated $\mathrm{Na}^{+}$channels and decreased $\mathrm{Na}^{+}$efflux from dysfunction of the membrane-bound $\mathrm{Na}^{+}-\mathrm{K}^{+}$-ATPase pump. ${ }^{2}$ The marked increase in intracellular $\mathrm{Na}^{+}$leads to an influx of $\mathrm{Ca}^{2+}$ through the $\mathrm{Na}^{+}-\mathrm{Ca}^{2+}$ exchange pump. This in turn activates a number of $\mathrm{Ca}^{2+}$-dependent enzyme systems, such as calpains and phospholipases, leading to regional cell death. ${ }^{156}$ This pathophysiological pathway, which centers on $\mathrm{Na}^{+}$overload, affords an opportunity to curb the extent of injury, preserve remnant viable neurological tissue, and improve clinical outcomes, and it provides the rationale for the use of sodium channel-blocking agents for neuroprotection in SCI ${ }^{160}$ In addition to its ability to reduce intracellular levels of $\mathrm{Na}^{+}$and $\mathrm{Ca}^{2+}$, riluzole functions as an anti-glutamatergic agent via inhibition of glutamate release, prevention of glutamate receptor hypofunction, and activation of glutamate transporters to increase glutamate uptake. ${ }^{55,87}$ The multifaceted effects of riluzole on excitotoxicity and neuromodulation make it a promising neuroprotective treatment option for patients who have suffered SCI.

There is strong evidence from a number of independent studies, using several different animal models of brain and spinal cord ischemic and traumatic injury, that riluzole is neuroprotective and promotes functional recovery. ${ }^{13,95,145,181}$ In preclinical animal models of SCI, riluzole has been 
TABLE 3. Summary of active phase III RCTs for traumatic SCI

\begin{tabular}{|c|c|c|c|c|c|c|c|}
\hline Trial & $\begin{array}{l}\text { Active } \\
\text { Centers }\end{array}$ & $\stackrel{\text { Target }}{\mathrm{N}}$ & Eligibility Criteria & Intervention & Control & $\begin{array}{l}\text { Primary } \\
\text { Outcome }\end{array}$ & Secondary Outcomes \\
\hline $\begin{array}{l}\text { RISCIS } \\
\quad \text { (riluzole) }\end{array}$ & $\begin{array}{c}23 \text { (3 Canada, } \\
16 \text { USA, } 4 \\
\text { Australia) }\end{array}$ & 351 & $\begin{array}{l}\text { Age } 18-75 \text { yrs; AIS } \\
\text { grade A, B, or C; } \\
\text { neurological level } \\
\text { btwn C4 \& C8; able } \\
\text { to receive drug w/in } \\
12 \text { hrs of injury }\end{array}$ & $\begin{array}{l}\text { Riluzole PO/NG } 100 \text { mg BID } \\
\times 24 \text { hrs then } 50 \text { mg BID } \\
\times 13 \text { days after injury }\end{array}$ & $\begin{array}{l}\text { Placebo PO/ } \\
\text { NG BID } \\
\times 14 \text { days }\end{array}$ & $\begin{array}{l}\text { Change in ASIA } \\
\text { motor score } \\
\text { at } 180 \text { days }\end{array}$ & $\begin{array}{l}\text { AIS grade, ASIA sen- } \\
\text { sory scores, SCIM, } \\
\text { SF-36, EQ-5D, pain } \\
\text { NRS, GRASSP (180 } \\
\text { days) }\end{array}$ \\
\hline $\begin{array}{l}\text { MASC } \\
\text { (minocy- } \\
\text { cline) }\end{array}$ & $\begin{array}{l}4 \text { (3 Canada, } \\
1 \text { Australia) }\end{array}$ & 248 & $\begin{array}{l}\text { Age } \geq 16 \text { yrs; neuro- } \\
\text { logical level btwn } \\
\text { C0 \& C8; able to } \\
\text { receive drug w/in } \\
12 \text { hrs of injury }\end{array}$ & $\begin{array}{l}\text { Minocycline IV BID ×7 days: } \\
800+700 \text { mg day } 1 ; 600 \\
+500 \mathrm{mg} \text { day } 2 ; 400+ \\
400 \mathrm{mg} \text { days } 3-7\end{array}$ & $\begin{array}{l}\text { Placebo (nor- } \\
\text { mal saline) } \\
\text { IV BID } \times 7 \\
\text { days }\end{array}$ & $\begin{array}{l}\text { Change in ASIA } \\
\text { motor score } \\
\text { from base- } \\
\text { line to btwn } \\
3 \text { mos \& } 1 \text { yr } \\
\text { post-injury }\end{array}$ & $\begin{array}{l}\text { ASIA sensory scores, } \\
\text { SCIM, SF-36, AIS } \\
\text { grade }\end{array}$ \\
\hline $\begin{array}{l}\text { SPRING } \\
\quad(V X-210)\end{array}$ & $\begin{array}{c}36 \text { (28 USA, } 8 \\
\text { Canada) }\end{array}$ & 150 & $\begin{array}{l}\text { Age 14-75 yrs; AIS } \\
\text { grade A or B; } \\
\text { motor level btwn } \\
\text { C4 \& C7 on each } \\
\text { side; scheduled to } \\
\text { undergo surgery } \\
\text { w/in } 72 \text { hrs of injury }\end{array}$ & $\begin{array}{l}\text { VX-210 } 9 \mathrm{mg} \text { in fibrin sealant } \\
\quad \text { (local admin) }\end{array}$ & $\begin{array}{l}\text { Placebo (buf- } \\
\text { fer solution) } \\
\text { in fibrin } \\
\text { sealant (lo- } \\
\text { cal admin) }\end{array}$ & $\begin{array}{l}\text { Change in } \\
\text { ASIA upper- } \\
\text { extremity } \\
\text { motor score } \\
\text { at } 6 \text { mos }\end{array}$ & $\begin{array}{l}\text { SCIM, CUE-T, } \\
\text { GRASSP, AIS grade } \\
\text { conversion, motor } \\
\text { level change (6 } \\
\text { mos); pharmaco- } \\
\text { kinetic parameters } \\
\text { of VX-210 (Tmax, } \\
\text { Cmax, AUC) at } 48 \\
\text { hrs after treatment }\end{array}$ \\
\hline FES & 1 (Canada) & 25 & $\begin{array}{l}\text { Age } \geq 18 \text { yrs; incom- } \\
\text { plete SCI btwn C4 } \\
\text { \& C7; less than } 6 \\
\text { mos post-injury; } \\
\text { unable to grasp } \\
\text { objects }\end{array}$ & $\begin{array}{l}\text { FES (balanced, biphasic, } \\
\text { current regulated electri- } \\
\text { cal pulses; pulse ampli- } \\
\text { tude from } 8 \text { to } 50 \mathrm{~mA} \text {; } \\
\text { pulse width from } 250 \text { to } \\
300 \mu \mathrm{sec} \text {; pulse frequency } \\
\text { from } 20 \text { to } 70 \mathrm{~Hz} \text { ) }\end{array}$ & $\begin{array}{l}\text { Conventional } \\
\text { OT }\end{array}$ & $\begin{array}{l}\text { Change in FIM } \\
\text { score from } \\
\text { baseline at } \\
8 \text { wks \& at } \\
6 \text {-mo follow- } \\
\text { up }\end{array}$ & $\begin{array}{l}\text { GRASSP, Jamar } \\
\text { hydraulic hand dyna- } \\
\text { mometer, Action } \\
\text { Research Arm Test, } \\
\text { TR-HFT, ReJoyce } \\
\text { therapy device, } \\
\text { SCIM (8 wks, } 6 \text { mos) }\end{array}$ \\
\hline $\begin{array}{l}\text { ES135/ } \\
\text { rhFGF1 }\end{array}$ & 3 (Taiwan) & 100 & $\begin{array}{l}\text { Age } 18-65 \text { yrs; AIS } \\
\text { grade A }\end{array}$ & $\begin{array}{l}\text { ES135 administered intrathe- } \\
\text { cally }\end{array}$ & $\begin{array}{l}\text { Placebo ad- } \\
\text { ministered } \\
\text { intrathecally }\end{array}$ & $\begin{array}{l}\text { Change in ASIA } \\
\text { motor score } \\
\text { at } 48 \text { wks }\end{array}$ & \\
\hline
\end{tabular}

Admin = administration; BID = twice daily; CUE-T = Capabilities of Upper Extremity Test; NG = nasogastric (by nasogastric tube); NRS = numeric rating scale; OT = occupational therapy; TR-HFT = Toronto Rehabilitation Institute Hand Function Test.

found to attenuate secondary injury pathways, increase neural tissue preservation at the site of injury, and improve neurobehavioral outcomes in comparison to placebo and other sodium channel-blocking medications. ${ }^{145,146,182,183}$ On the basis of promising preclinical data, a phase I clinical trial investigating the safety and pharmacokinetics of riluzole in the setting of acute traumatic SCI was undertaken (NCT00876889). ${ }^{59}$ For the 36 enrolled patients, this study found improved ASIA motor scores, particularly for cervical SCI cases, and a similar complication profile compared to 36 matched patients in the North American Clinical Trials Network (NACTN) SCI Registry. These results provided the impetus for a phase IIb/III clinical trial, Riluzole in Acute Spinal Cord Injury Study (RISCIS), which commenced in January 2014 and is currently ongoing (NCT01597518). ${ }^{40}$

RISCIS is a multicenter, double-blinded, placebo-controlled, 2-arm parallel group superiority RCT with a sequential adaptive design. Adult patients (age 18-75 years) with AIS grade A, B, or C SCI and a neurological level between $\mathrm{C} 4$ and $\mathrm{C} 8$ presenting within 12 hours of injury are randomized in a 1:1 ratio to receive riluzole (100 $\mathrm{mg}$ twice a day for 24 hours, then $50 \mathrm{mg}$ twice a day for 13 days after injury) or placebo. The primary outcome is change in ASIA motor score from baseline to 180 days after injury. Secondary outcomes include overall neurological recovery (AIS grade), sensory recovery (ASIA Light Touch and Pin Prick scores), functional outcomes (SCIM), quality of life (SF-36, EQ-5D), pain (numeric rating scale), sensorimotor upper limb function (Graded Redefined Assessment of Strength Sensibility and Prehension [GRASSP]), mortality, and adverse events. Patients, physicians, and data collectors remain blinded to treatment group allocation throughout randomization and follow-up.

\section{MASC-Minocycline}

The antibiotic minocycline has demonstrated neuroprotective properties in preclinical studies. ${ }^{187}$ Specifically, minocycline has been found to reduce apoptosis of oligodendrocytes and microglia and improve neurological recovery in rodent models of SCI..$^{100,174}$ A phase II trial of minocycline for acute traumatic SCI was completed and published in 2012. ${ }^{21}$ Fifty-two patients were randomly as- 
signed to receive minocycline $(\mathrm{N}=27)$ or placebo $(\mathrm{N}=25)$. Compared to patients in the placebo arm, patients treated with minocycline experienced a 6-point greater recovery in ASIA motor score at 1 year, although the difference was not statistically significant. While no difference was observed for thoracic injuries, a trend toward improved motor recovery with minocycline (14-point difference in ASIA motor score) was observed for cervical cases $(p=0.05)$. A phase III RCT, Minocycline in Acute Spinal Cord Injury (MASC), has been initiated (NCT01828203).

MASC is a multicenter, placebo-controlled, doubleblinded RCT. The target enrollment is 248 patients. Adult patients (age $\geq 16$ years) with cervical SCI presenting within 12 hours of injury are randomly assigned to IV minocycline (800-mg initial dose tapered to $400 \mathrm{mg}$ by 100 $\mathrm{mg}$ at each dose and then administered to the end of day 7) or placebo. The primary outcome is recovery in ASIA motor score measured between 3 months and 1 year postinjury. Secondary outcomes include ASIA sensory recovery, functional outcome (SCIM), quality of life (SF-36), and overall neurological function (AIS grade).

\section{SPRING-VX-210}

Following CNS injury, there is inhibition of axonal growth and regeneration. Several growth inhibitory pathways converge in signaling to Rho, an intracellular GTPase. ${ }^{36}$ Activation of Rho and downstream activation of Rho-associated kinase leads to an imbalance in the phosphorylation state of myosin light chain and, as a consequence, a collapse of the growth cone scaffold and axon growth arrest. ${ }^{47} \mathrm{C} 3$ transferase, an enzyme derived from Clostridium botulinum, locks RhoA in the inactive state and thereby inhibits Rho signaling. C3 transferase has been shown to promote axonal outgrowth on inhibitory substrates both in vitro and in vivo. ${ }^{36,116} \mathrm{VX}-210$ is a recombinant engineered variant of C3 transferase that can readily cross the spinal cord dura and permeate across the cell membrane through a receptor-independent mechanism. ${ }^{116}$ In a rodent thoracic spinal cord contusion model, local delivery of VX-210 to the injury site has been found to inactivate RhoA, reduce the extent of the lesion, and improve locomotor function. ${ }^{116} \mathrm{~A}$ phase I/IIa clinical trial was undertaken. ${ }^{47}$ Forty-eight patients with an AIS A cervical or thoracic SCI received 0.3 to $9 \mathrm{mg}$ Cethrin applied locally onto the anterior or posterior dural surface overlying the injured spinal cord at the time of surgery. Changes in ASIA motor scores were small in all thoracic SCI patients $(1.8 \pm 5.1)$ and larger in cervical SCI patients $(18.6 \pm 19.3)$. Cervical SCI patients treated with $3 \mathrm{mg}$ of Cethrin experienced the greatest improvement in ASIA motor score at 1 year $(27.3 \pm 13.3)$. Based on this experience, a phase IIb/ III trial of VX-210 for acute traumatic cervical SCI, the SPRING (SPinal Cord Injury Rho INhibition InvestiGation), is now underway (NCT02669849).

The SPRING trial is designed as a multicenter, double-blinded, placebo-controlled, prospective randomized study. Eligibility criteria are age 14 to 75 years; AIS A or B acute traumatic SCI with a motor level between C4 and C7; and ability to undergo surgery within 72 hours of injury. The target enrollment is 150 patients. The primary outcome is change in ASIA upper-extremity motor score from baseline to 6 months post-injury. Secondary outcomes at 6 months include functional status (SCIM), sensorimotor upper limb function (GRASSP), AIS grade conversion, and ASIA motor level change, in addition to pharmacokinetic parameters of VX-210 (Tmax [time taken to reach the maximum concentration], Cmax [maximum concentration], and AUC [area under the curve]).

\section{ES135/rhFGF1}

Fibrin glue containing acidic fibroblast growth factor (aFGF) has been studied as a possible repair strategy for SCI. In animal studies, aFGF, in conjunction with a peripheral nerve graft, has demonstrated potential to support axonal regeneration and formation of white matter to gray matter connections. ${ }^{24,101}$ This was tested in a human for the first time in 2004. ${ }^{25}$ The patient was a young male with chronic paraplegia and a complete spinal cord gap resulting from a stabbing injury. The technique involved bridging the spinal cord gap with sural nerve grafts and applying fibrin glue mixed with aFGF to the grafted area. This patient improved from being wheelchair-bound to being able to ambulate independently with a walker. A phase I pilot study tested local application of fibrin glue with aFGF without nerve grafting in 9 patients with chronic SCI (> 5 months).$^{180}$ The procedure was well tolerated, and the patients demonstrated significant improvement in ASIA motor and sensory scores. In a subsequent larger trial that involved 49 chronic SCI patients, application of aFGF with fibrin glue and duraplasty performed via laminectomy was combined with adjuvant booster treatment of combined aFGF and fibrin glue at 3 and 6 months postsurgery via lumbar puncture. ${ }^{79}$ Again, the use of aFGF was found to be safe and feasible; significant improvements were seen in ASIA motor and sensory scale scores, AIS grade, neurological level, and Functional Independence Measure (FIM) score at 24 months after treatment. A phase III multicenter, double-blinded, placebo-controlled, randomized trial of aFGF (ES135; EUSOL Biotech Co., Ltd.) is currently enrolling patients (NCT03229031). Eligible patients are 18 to 65 years of age and have an AIS A SCI. The target enrollment is 100 patients. The primary outcome is change in ASIA motor score at 12 months.

\section{Functional Electrical Stimulation}

Functional electrical stimulation (FES) involves the application of electrical stimulus to generate muscle contractions in a carefully timed and orchestrated fashion that allows for functional limb use. FES has been successfully applied to improve ambulatory ability in patients with incomplete SCI. ${ }^{77,165}$ Similarly, muscle contraction may be coordinated to produce grasp opening and closing; thumb opening, closing, and positioning; wrist flexion and extension; forearm pronation; and elbow extension. ${ }^{69} \mathrm{~A}$ phase III multicenter randomized trial (NCT01292811) of FES compared to conventional occupational therapy for restoration of upper limb function is currently ongoing. The primary outcome is change in burden of care from baseline at 8 weeks to 6 -month follow-up, as evaluated by FIM. Secondary outcomes include change in sensorimotor upper limb function (GRASSP), grip force (measured using a Jamar hydraulic hand dynamometer), and SCIM score. 


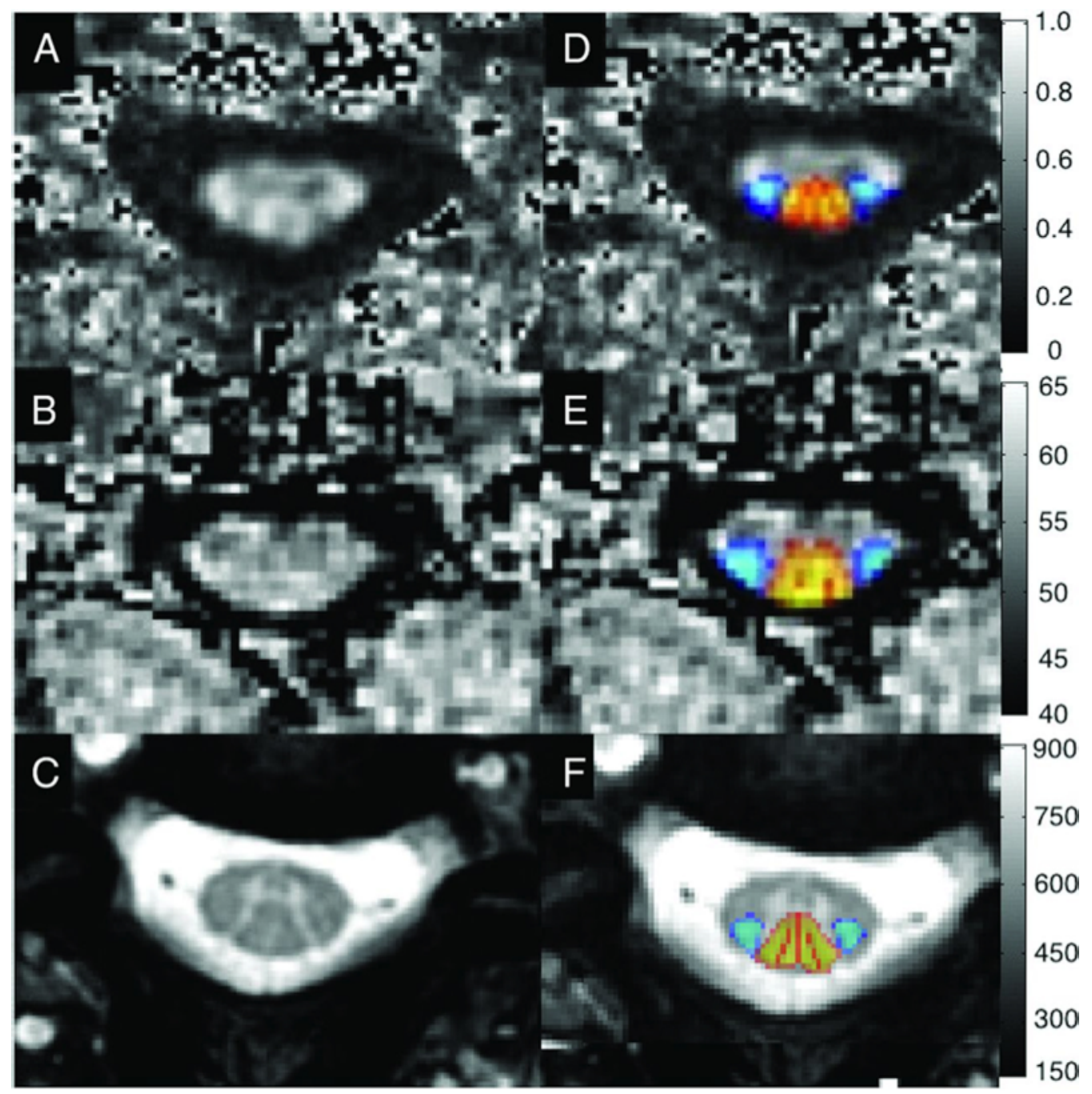

FIG. 2. Representative axial MR images showing functional anisotropy (FA) mapping (A), MTR mapping (B), and T2*-weighted imaging $(\mathbf{C})$ with probabilistic maps of the lateral corticospinal tracts (blue) and dorsal columns (red-yellow) overlaid (D-F) following registration to the Spinal Cord Toolbox (SCT; https://www.nitrc.org/projects/sct//31 atlas. Reprinted with permission from Martin AR, De Leener B, Cohen-Adad J, Cadotte DW, Kalsi-Ryan S, Lange SF, et al: Clinically feasible microstructural MRI to quantify cervical spinal cord tissue injury using DTI, MT, and T2*-weighted imaging: assessment of normative data and reliability. AJNR Am $J$ Neuroradiol 38:1257-1265, 2017. Figure is available in color online only.

\section{Biomarkers}

There is a critical need for improved prognostication in SCI. To this end, there has been much interest in identifying and characterizing imaging, serum, and CSF biomarkers that may quantify the degree of neural tissue injury and predict neurological outcomes. In addition to guiding patient counseling and calibration of expectations, these may facilitate stratification of patients for enrollment into clinical trials. The use of biomarkers could also permit the enrollment of patients who cannot be adequately examined because of head injury, multisystem trauma, drug intoxication, or pharmacological sedation, and in doing so, may facilitate the translation of novel therapies for acute traumatic SCI.

\section{Imaging}

Our ability to image the injured spinal cord at high res- olution has improved substantially over recent years. With the development of advanced spinal MRI protocols with acquisition times under 35 minutes, it is now clinically feasible to obtain microstructural MRI sequences, including DTI, magnetization transfer (MT), and T2*-weighted imaging, in the setting of acute traumatic SCI. ${ }^{118}$ Quantitative metrics derived from these modalities have potential to serve as biomarkers to quantify cervical spinal cord tissue injury. In particular, the signal intensity ratio of white matter to gray matter on $\mathrm{T} 2{ }^{*}$-weighted imaging has been found to correlate strongly with focal motor and sensory deficits, more so than cross-sectional area, fractional anisotropy, or MT ratio (MTR) (Fig. 2). ${ }^{119}$

\section{Cerebrospinal Fluid}

Molecular profiling of CSF in the setting of SCI has been an active area of investigation. Kwon et al. ${ }^{90}$ random- 
ly assigned 22 patients with acute traumatic SCI to CSFdrainage (via lumbar intrathecal catheter) or no-drainage groups. This trial confirmed the safety of CSF drainage, but it also enabled biochemical analysis of CSF samples collected through the drains. Key inflammatory cytokines (e.g., interleukin [IL]-6, IL-8, and monocyte chemotactic protein [MCP]-1) and structural proteins (e.g., tau, S100 $\beta$, and glial fibrillary acidic protein [GFAP]) were temporally profiled. An ordinal logistic regression model could predict the observed AIS grade with $89 \%$ accuracy based on concentrations of S100 $\beta$, GFAP, and IL-8 at 24 hours post-SCI. ${ }^{91}$ Moreover, in patients with cervical injury, concentrations of these proteins could predict upper-extremity motor recovery at 6 months better than baseline AIS grade. In addition, CSF levels of TNF-R1 at 24 hours correlated strongly with neuropathic pain. This study has been expanded to a prospective, multicenter initiative, known as the Canadian Multicentre CSF Monitoring and Biomarker Study (CAMPER; NCT01279811). Analysis of the first 50 patients enrolled in this study found CSF concentrations of IL-6, tau, S100 $\beta$, and GFAP at 24 hours to be significantly different between patients with AIS A, B, and C injuries. $^{92}$ Discriminant analysis based on levels of IL-6, IL8 , MCP-1, tau, S100 $\beta$, and GFAP showed $83.3 \%$ accuracy in predicting AIS grade conversion at 6-month follow-up. Additionally, all of these CSF biomarkers showed significant correlation with ASIA motor score improvement, especially for cervical SCI patients. A recent study of MRI (intramedullary lesion length, hematoma length, hematoma extent, CSF effacement, cord expansion, maximal spinal cord compression) and CSF (IL-6, IL-8, MCP-1, tau, GFAP, S100 $\beta$ ) biomarkers found that both correlated with baseline AIS grade; however, ability to predict baseline AIS grade was maximized when both were combined together..$^{30}$ In direct head-to-head comparison, CSF biomarkers were found to better discriminate between injury severities, and more accurately predict neurological recovery (AIS grade conversion, ASIA motor score improvement) than MRI biomarkers.

\section{Serum}

Evaluation of serum proteins, too, holds promise. In a cohort of 35 patients with acute traumatic SCI, Ahadi et al. ${ }^{3}$ observed increased serum levels of GFAP, neuronspecific enolase (NSE), and the phosphorylated form of the heavy subunit of neurofilament (pNF-H). GFAP levels correlated with severity of SCI. Kuhle et al.$^{88}$ found that serum neurofilament light chain (NF-L) concentrations closely correlated with ASIA motor score at baseline and after 24 hours and with 3- to 12-month motor outcome. Further, minocycline treatment was associated with lower levels of NF-L in patients with motor complete SCI. This last finding highlights the possibility of using biomarkers as surrogate outcomes in SCI clinical trials.

\section{Future Directions}

A number of promising neuroprotective and regenerative therapies for acute traumatic SCI are under active investigation, and several more are coming down the translational pipeline. There is reason to hope that in the near future development of a biomarker readout from a combi- nation of imaging, serum, and CSF analysis may improve prognostication for patients with SCI and further facilitate the translation of novel therapeutics from bench to bedside through clinical trials. With the organization of large, multicenter, and in some cases multinational, prospective registries of SCI and the collection of mass data relating to clinical characteristics, imaging features, serum markers, and CSF markers, the application of machine learning and big data analytical approaches may pave the way toward precision and personalized medicine for traumatic SCI. Further, regional and national efforts to organize healthcare systems infrastructure to facilitate early transfer of SCI patients to centers specializing in the care of patients with these injuries may improve clinical outcomes on a large scale.

\section{References}

1. Ackery A, Tator C, Krassioukov A: A global perspective on spinal cord injury epidemiology. J Neurotrauma 21:13551370, 2004

2. Agrawal SK, Fehlings MG: Mechanisms of secondary injury to spinal cord axons in vitro: role of $\mathrm{Na}+, \mathrm{Na}(+)-\mathrm{K}(+)-$ ATPase, the $\mathrm{Na}(+)-\mathrm{H}+$ exchanger, and the $\mathrm{Na}(+)-\mathrm{Ca} 2+$ exchanger. J Neurosci 16:545-552, 1996

3. Ahadi R, Khodagholi F, Daneshi A, Vafaei A, Mafi AA, Jorjani M: Diagnostic value of serum levels of GFAP, pNF$\mathrm{H}$, and NSE compared with clinical findings in severity assessment of human traumatic spinal cord injury. Spine (Phila Pa 1976) 40:E823-E830, 2015

4. Ahuja C, Fehlings M: Neuroprotection of the injured spinal cord - what does the future hold? in Vialle L (ed): AOSpine Master Series. Spinal Cord Injury and Regeneration, Vol 7. New York: Thieme, 2017

5. Ahuja CS, Fehlings MG: Spinal cord injury, in Ellenbogen RG, Sekhar LN, Kitchen ND (eds): Principles of Neurological Surgery, ed 4. Philadelphia: Elsevier Health Sciences, 2018

6. Ahuja CS, Martin AR, Fehlings M: Recent advances in managing a spinal cord injury secondary to trauma. F1000 Res 5:5, 2016

7. Ahuja CS, Nori S, Tetreault L, Wilson J, Kwon B, Harrop J, et al: Traumatic spinal cord injury-repair and regeneration. Neurosurgery 80 (3S):S9-S22, 2017

8. Ahuja CS, Schroeder GD, Vaccaro AR, Fehlings MG: Spinal cord injury - what are the controversies? J Orthop Trauma 31 (Suppl 4):S7-S13, 2017

9. Ahuja CS, Wilson JR, Nori S, Kotter MRN, Druschel C, Curt A, et al: Traumatic spinal cord injury. Nat Rev Dis Primers 3:17018, 2017

10. Anderson KK, Tetreault L, Shamji MF, Singh A, Vukas RR, Harrop JS, et al: Optimal timing of surgical decompression for acute traumatic central cord syndrome: a systematic review of the literature. Neurosurgery 77 (Suppl 4):S15S32, 2015

11. Arnold PM, Harrop JS, Merli G, Tetreault LG, Kwon BK, Casha S, et al: Efficacy, safety, and timing of anticoagulant thromboprophylaxis for the prevention of venous thromboembolism in patients with acute spinal cord injury: a systematic review. Global Spine J 7 (3 Suppl):138S-150S, 2017

12. Assinck P, Duncan GJ, Hilton BJ, Plemel JR, Tetzlaff W: Cell transplantation therapy for spinal cord injury. Nat Neurosci 20:637-647, 2017

13. Ates O, Cayli SR, Gurses I, Turkoz Y, Tarim O, Cakir CO, et al: Comparative neuroprotective effect of sodium channel blockers after experimental spinal cord injury. J Clin Neurosci 14:658-665, 2007 
14. Biernaskie J, Sparling JS, Liu J, Shannon CP, Plemel JR, Xie Y, et al: Skin-derived precursors generate myelinating Schwann cells that promote remyelination and functional recovery after contusion spinal cord injury. J Neurosci 27:9545-9559, 2007

15. Bötel U, Gläser E, Niedeggen A: The surgical treatment of acute spinal paralysed patients. Spinal Cord 35:420-428, 1997

16. Bracken MB, Shepard MJ, Collins WF, Holford TR, Young W, Baskin DS, et al: A randomized, controlled trial of methylprednisolone or naloxone in the treatment of acute spinal-cord injury. Results of the Second National Acute Spinal Cord Injury Study. N Engl J Med 322:1405-1411, 1990

17. Bracken MB, Shepard MJ, Holford TR, Leo-Summers L, Aldrich EF, Fazl M, et al: Administration of methylprednisolone for 24 or 48 hours or tirilazad mesylate for 48 hours in the treatment of acute spinal cord injury. Results of the Third National Acute Spinal Cord Injury Randomized Controlled Trial. National Acute Spinal Cord Injury Study. JAMA 277:1597-1604, 1997

18. Brommer B, Engel O, Kopp MA, Watzlawick R, Müller S, Prüss H, et al: Spinal cord injury-induced immune deficiency syndrome enhances infection susceptibility dependent on lesion level. Brain 139:692-707, 2016

19. Burns AS, Marino RJ, Kalsi-Ryan S, Middleton JW, Tetreault LA, Dettori JR, et al: Type and timing of rehabilitation following acute and subacute spinal cord injury: a systematic review. Global Spine J 7 (3 Suppl):175S-194S, 2017

20. Cafferty WB, Duffy P, Huebner E, Strittmatter SM: MAG and OMgp synergize with Nogo-A to restrict axonal growth and neurological recovery after spinal cord trauma. $\mathbf{J}$ Neurosci 30:6825-6837, 2010

21. Casha S, Zygun D, McGowan MD, Bains I, Yong VW, Hurlbert RJ: Results of a phase II placebo-controlled randomized trial of minocycline in acute spinal cord injury. Brain 135: 1224-1236, 2012

22. Chen MS, Huber AB, van der Haar ME, Frank M, Schnell L, Spillmann AA, et al: Nogo-A is a myelin-associated neurite outgrowth inhibitor and an antigen for monoclonal antibody IN-1. Nature 403:434-439, 2000

23. Chen W, Baylink DJ, Lau KH, Zhang XB: Generation of mesenchymal stem cells by blood cell reprogramming. Curr Stem Cell Res Ther 11:114-121, 2016

24. Cheng H, Cao Y, Olson L: Spinal cord repair in adult paraplegic rats: partial restoration of hind limb function. Science 273:510-513, 1996

25. Cheng H, Liao KK, Liao SF, Chuang TY, Shih YH: Spinal cord repair with acidic fibroblast growth factor as a treatment for a patient with chronic paraplegia. Spine (Phila Pa 1976) 29:E284-E288, 2004

26. Choo AM, Liu J, Lam CK, Dvorak M, Tetzlaff W, Oxland TR: Contusion, dislocation, and distraction: primary hemorrhage and membrane permeability in distinct mechanisms of spinal cord injury. J Neurosurg Spine 6:255-266, 2007

27. Christopher and Dana Reeve Foundation: One Degree of Separation: Paralysis and Spinal Cord Injury in the United States. Short Hills, NJ: Christopher and Dana Reeve Foundation, 2010 (http://s3 amazonaws.com/reeve-assetsproduction/8112REPTFINAL.PDF) [Accessed October 8, 2018]

28. Couris CM, Guilcher SJ, Munce SE, Fung K, Craven BC, Verrier M, et al: Characteristics of adults with incident traumatic spinal cord injury in Ontario, Canada. Spinal Cord 48:39-44, 2010

29. Coxe WS, Landau WM: Patterns of Marchi degeneration in the monkey pyramidal tract following small discrete cortical lesions. Neurology 20:89-100, 1970
30. Dalkilic T, Fallah N, Noonan VK, Salimi Elizei S, Dong $\mathrm{K}$, Belanger L, et al: Predicting injury severity and neurological recovery after acute cervical spinal cord injury: a comparison of cerebrospinal fluid and magnetic resonance imaging biomarkers. J Neurotrauma 35:435-445, 2018

31. Dasari VR, Veeravalli KK, Dinh DH: Mesenchymal stem cells in the treatment of spinal cord injuries: a review. World J Stem Cells 6:120-133, 2014

32. De Leener B, Lévy S, Dupont SM, Fonov VS, Stikov N, Louis Collins D, et al: SCT: Spinal Cord Toolbox, an open-source software for processing spinal cord MRI data. Neuroimage 145 (Pt A):24-43, 2017

33. DeVivo MJ: Causes and costs of spinal cord injury in the United States. Spinal Cord 35:809-813, 1997

34. Devivo MJ: Epidemiology of traumatic spinal cord injury: trends and future implications. Spinal Cord 50:365-372, 2012

35. Dizdaroglu M, Jaruga P, Birincioglu M, Rodriguez H: Free radical-induced damage to DNA: mechanisms and measurement. Free Radic Biol Med 32:1102-1115, 2002

36. Dubreuil CI, Winton MJ, McKerracher L: Rho activation patterns after spinal cord injury and the role of activated Rho in apoptosis in the central nervous system. J Cell Biol 162: 233-243, 2003

37. Dulamea A: Mesenchymal stem cells in multiple sclerosistranslation to clinical trials. J Med Life 8:24-27, 2015

38. Ekberg JA, St John JA: Olfactory ensheathing cells for spinal cord repair: crucial differences between subpopulations of the glia. Neural Regen Res 10:1395-1396, 2015

39. Fehlings MG, Martin AR, Tetreault LA, Aarabi B, Anderson P, Arnold PM, et al: A clinical practice guideline for the management of patients with acute spinal cord injury: recommendations on the role of baseline magnetic resonance imaging in clinical decision making and outcome prediction. Global Spine J 7 (3 Suppl):221S-230S, 2017

40. Fehlings MG, Nakashima H, Nagoshi N, Chow DS, Grossman RG, Kopjar B: Rationale, design and critical end points for the Riluzole in Acute Spinal Cord Injury Study (RISCIS): a randomized, double-blinded, placebo-controlled parallel multi-center trial. Spinal Cord 54:8-15, 2016

41. Fehlings MG, Rabin D, Sears W, Cadotte DW, Aarabi B: Current practice in the timing of surgical intervention in spinal cord injury. Spine (Phila Pa 1976) 35 (21 Suppl):S166-S173, 2010

42. Fehlings MG, Tetreault LA, Aarabi B, Anderson P, Arnold PM, Brodke DS, et al: A clinical practice guideline for the management of patients with acute spinal cord injury: recommendations on the type and timing of anticoagulant thromboprophylaxis. Global Spine J 7 (3 Suppl):212S220S, 2017

43. Fehlings MG, Tetreault LA, Aarabi B, Anderson P, Arnold PM, Brodke DS, et al: A clinical practice guideline for the management of patients with acute spinal cord injury: recommendations on the type and timing of rehabilitation. Global Spine J 7 (3 Suppl):231S-238S, 2017

44. Fehlings MG, Tetreault L, Nater A, Choma T, Harrop J, Mroz T, et al: The aging of the global population: the changing epidemiology of disease and spinal disorders. Neurosurgery 77 (Suppl 4):S1-S5, 2015

45. Fehlings MG, Tetreault LA, Wilson JR, Aarabi B, Anderson P, Arnold PM, et al: A clinical practice guideline for the management of patients with acute spinal cord injury and central cord syndrome: recommendations on the timing $(\leq 24$ hours versus $>24$ hours) of decompressive surgery. Global Spine J 7 (3 Suppl): 195S-202S, 2017

46. Fehlings MG, Tetreault LA, Wilson JR, Kwon BK, Burns AS, Martin AR, et al: A clinical practice guideline for the management of acute spinal cord injury: introduction, rationale, and scope. Global Spine J 7 (3 Suppl):84S-94S, 2017 
47. Fehlings MG, Theodore N, Harrop J, Maurais G, Kuntz C, Shaffrey CI, et al: A phase I/IIa clinical trial of a recombinant Rho protein antagonist in acute spinal cord injury. J Neurotrauma 28:787-796, 2011

48. Fehlings MG, Vaccaro A, Wilson JR, Singh A, W Cadotte D, Harrop JS, et al: Early versus delayed decompression for traumatic cervical spinal cord injury: results of the Surgical Timing in Acute Spinal Cord Injury Study (STASCIS). PLoS One 7:e32037, 2012

49. Fehlings MG, Wilson JR, Harrop JS, Kwon BK, Tetreault LA, Arnold PM, et al: Efficacy and safety of methylprednisolone sodium succinate in acute spinal cord injury: a systematic review. Global Spine J 7 (3 Suppl):116S-137S, 2017

50. Fehlings MG, Wilson JR, Tetreault LA, Aarabi B, Anderson $\mathrm{P}$, Arnold PM, et al: A clinical practice guideline for the management of patients with acute spinal cord injury: recommendations on the use of methylprednisolone sodium succinate. Global Spine J 7 (3 Suppl):203S-211S, 2017

51. Fellows CR, Matta C, Zakany R, Khan IM, Mobasheri A: Adipose, bone marrow and synovial joint-derived mesenchymal stem cells for cartilage repair. Front Genet 7:213, 2016

52. Foerster O: Symptomatologie der Erkrankungen des Rückenmarks und seiner Wurzeln, in Bumke O, Foerster O (eds): Handbook of Neurology. Berlin: Springer, 1936, Vol $5, \mathrm{p} 83$

53. Forgione N, Fehlings MG: Rho-ROCK inhibition in the treatment of spinal cord injury. World Neurosurg 82:e535e539, 2014

54. Führmann T, Tam RY, Ballarin B, Coles B, Elliott Donaghue I, van der Kooy D, et al: Injectable hydrogel promotes early survival of induced pluripotent stem cellderived oligodendrocytes and attenuates longterm teratoma formation in a spinal cord injury model. Biomaterials 83:23-36, 2016

55. Fumagalli E, Funicello M, Rauen T, Gobbi M, Mennini $\mathrm{T}$ : Riluzole enhances the activity of glutamate transporters GLAST, GLT1 and EAAC1. Eur J Pharmacol 578:171176, 2008

56. Furlan JC, Noonan V, Cadotte DW, Fehlings MG: Timing of decompressive surgery of spinal cord after traumatic spinal cord injury: an evidence-based examination of preclinical and clinical studies. J Neurotrauma 28:1371-1399, 2011

57. Glennie RA, Bailey CS, Tsai EC, Noonan VK, Rivers CS, Fourney DR, et al: An analysis of ideal and actual time to surgery after traumatic spinal cord injury in Canada. Spinal Cord 55:618-623, 2017

58. Gritti A, Parati EA, Cova L, Frolichsthal P, Galli R, Wanke E, et al: Multipotential stem cells from the adult mouse brain proliferate and self-renew in response to basic fibroblast growth factor. J Neurosci 16: 1091-1100, 1996

59. Grossman RG, Fehlings MG, Frankowski RF, Burau KD, Chow DS, Tator C, et al: A prospective, multicenter, phase I matched-comparison group trial of safety, pharmacokinetics, and preliminary efficacy of riluzole in patients with traumatic spinal cord injury. J Neurotrauma 31:239-255, 2014

60. Gupta D, Tator CH, Shoichet MS: Fast-gelling injectable blend of hyaluronan and methylcellulose for intrathecal, localized delivery to the injured spinal cord. Biomaterials 27:2370-2379, 2006

61. Guyatt GH, Oxman AD, Kunz R, Falck-Ytter Y, Vist GE, Liberati A, et al: Going from evidence to recommendations. BMJ 336: 1049-1051, 2008

62. Guyatt GH, Oxman AD, Kunz R, Vist GE, Falck-Ytter Y, Schünemann HJ: What is "quality of evidence" and why is it important to clinicians? BMJ 336:995-998, 2008

63. Guyatt GH, Oxman AD, Vist GE, Kunz R, Falck-Ytter Y,
Alonso-Coello P, et al: GRADE: an emerging consensus on rating quality of evidence and strength of recommendations. BMJ 336:924-926, 2008

64. Hachem LD, Ahuja CS, Fehlings MG: Assessment and management of acute spinal cord injury: From point of injury to rehabilitation. J Spinal Cord Med 40:665-675, 2017

65. Hadley MN, Walters BC, Grabb PA, Oyesiku NM, Przybylski GJ, Resnick DK, et al: Blood pressure management after acute spinal cord injury. Neurosurgery 50 (3 Suppl):S58-S62, 2002

66. Harrop JS, Sharan A, Ratliff J: Central cord injury: pathophysiology, management, and outcomes. Spine J 6 (6 Suppl):198S-206S, 2006

67. Hausmann ON: Post-traumatic inflammation following spinal cord injury. Spinal Cord 41:369-378, 2003

68. Healthcare Cost and Utilization Project (HCUP): NIS Database Documentation. Rockville, MD: Agency for Healthcare Research and Quality, 2017 (https://www. hcup-us.ahrq.gov/db/nation/nis/nisdbdocumentation.jsp) [Accessed October 8, 2018]

69. Ho CH, Triolo RJ, Elias AL, Kilgore KL, DiMarco AF, Bogie K, et al: Functional electrical stimulation and spinal cord injury. Phys Med Rehabil Clin N Am 25:631-654, ix, 2014

70. Honmou O, Felts PA, Waxman SG, Kocsis JD: Restoration of normal conduction properties in demyelinated spinal cord axons in the adult rat by transplantation of exogenous Schwann cells. J Neurosci 16:3199-3208, 1996

71. Ishida $\mathrm{Y}$, Tominaga $\mathrm{T}$ : Predictors of neurologic recovery in acute central cervical cord injury with only upper extremity impairment. Spine (Phila Pa 1976) 27:1652-1658, 2002

72. Iwasaki M, Wilcox JT, Nishimura Y, Zweckberger K, Suzuki H, Wang J, et al: Synergistic effects of self-assembling peptide and neural stem/progenitor cells to promote tissue repair and forelimb functional recovery in cervical spinal cord injury. Biomaterials 35:2617-2629, 2014

73. Jain NB, Ayers GD, Peterson EN, Harris MB, Morse L, O'Connor KC, et al: Traumatic spinal cord injury in the United States, 1993-2012. JAMA 313:2236-2243, 2015

74. Jimenez O, Marcillo A, Levi AD: A histopathological analysis of the human cervical spinal cord in patients with acute traumatic central cord syndrome. Spinal Cord 38:532-537, 2000

75. Jug M, Kejžar N, Vesel M, Al Mawed S, Dobravec M, Herman S, et al: Neurological recovery after traumatic cervical spinal cord injury is superior if surgical decompression and instrumented fusion are performed within 8 hours versus 8 to 24 hours after injury: a single center experience. J Neurotrauma 32:1385-1392, 2015

76. Kanno H, Pearse DD, Ozawa H, Itoi E, Bunge MB: Schwann cell transplantation for spinal cord injury repair: its significant therapeutic potential and prospectus. Rev Neurosci 26:121-128, 2015

77. Kapadia N, Masani K, Catharine Craven B, Giangregorio LM, Hitzig SL, Richards K, et al: A randomized trial of functional electrical stimulation for walking in incomplete spinal cord injury: effects on walking competency. J Spinal Cord Med 37:511-524, 2014

78. Karimi-Abdolrezaee S, Eftekharpour E, Wang J, Morshead CM, Fehlings MG: Delayed transplantation of adult neural precursor cells promotes remyelination and functional neurological recovery after spinal cord injury. J Neurosci 26:3377-3389, 2006

79. Kawabe J, Koda M, Hashimoto M, Fujiyoshi T, Furuya T, Endo T, et al: Neuroprotective effects of granulocyte colony-stimulating factor and relationship to promotion of angiogenesis after spinal cord injury in rats: laboratory investigation. J Neurosurg Spine 15:414-421, 2011

80. Keirstead HS, Nistor G, Bernal G, Totoiu M, Cloutier F, 
Sharp K, et al: Human embryonic stem cell-derived oligodendrocyte progenitor cell transplants remyelinate and restore locomotion after spinal cord injury. J Neurosci 25:4694-4705, 2005

81. Khazaei M, Ahuja CS, Fehlings MG: Generation of Oligodendrogenic Spinal Neural Progenitor Cells From Human Induced Pluripotent Stem Cells. Curr Protoc Stem Cell Biol 42:2D.20.1-2D.20.14, 2017

82. Khazaei M, Ahuja CS, Fehlings MG: Induced pluripotent stem cells for traumatic spinal cord injury. Front Cell Dev Biol 4:152, 2017

83. Khazaei MAC, Siddiqui AM, Fehlings MG: Transplantation of Human-Induced Pluripotent Stem Cell-Derived Neural Precursor Cells for Treatment of Spinal Cord Injury. Amsterdam: Elsevier, 2018

84. Kitamura K, Fujiyoshi K, Yamane J, Toyota F, Hikishima $\mathrm{K}$, Nomura T, et al: Human hepatocyte growth factor promotes functional recovery in primates after spinal cord injury. PLoS One 6:e27706, 2011

85. Kitamura K, Iwanami A, Fujiyoshi K, Yamane JI, Hikishima K, Funakoshi H, et al: Recombinant human hepatocyte growth factor promotes functional recovery after spinal cord injury, in Uchida K, Nakamura M, Ozawa H, et al (eds): Neuroprotection and Regeneration of the Spinal Cord. Tokyo: Springer Japan, 2014, pp 147-167

86. Knútsdóttir S, Thórisdóttir H, Sigvaldason K, Jónsson H Jr, Björnsson A, Ingvarsson P: Epidemiology of traumatic spinal cord injuries in Iceland from 1975 to 2009. Spinal Cord 50: $123-126,2012$

87. Kretschmer BD, Kratzer U, Schmidt WJ: Riluzole, a glutamate release inhibitor, and motor behavior. Naunyn Schmiedebergs Arch Pharmacol 358:181-190, 1998

88. Kuhle J, Gaiottino J, Leppert D, Petzold A, Bestwick JP, Malaspina A, et al: Serum neurofilament light chain is a biomarker of human spinal cord injury severity and outcome. J Neurol Neurosurg Psychiatry 86:273-279, 2015

89. Kurpad S, Martin AR, Tetreault LA, Fischer DJ, Skelly AC, Mikulis D, et al: Impact of baseline magnetic resonance imaging on neurologic, functional, and safety outcomes in patients with acute traumatic spinal cord injury. Global Spine J 7 (3 Suppl):151S-174S, 2017

90. Kwon BK, Curt A, Belanger LM, Bernardo A, Chan D, Markez JA, et al: Intrathecal pressure monitoring and cerebrospinal fluid drainage in acute spinal cord injury: a prospective randomized trial. J Neurosurg Spine 10:181-193, 2009

91. Kwon BK, Stammers AM, Belanger LM, Bernardo A, Chan $\mathrm{D}$, Bishop CM, et al: Cerebrospinal fluid inflammatory cytokines and biomarkers of injury severity in acute human spinal cord injury. J Neurotrauma 27:669-682, 2010

92. Kwon BK, Streijger F, Fallah N, Noonan VK, Bélanger LM, Ritchie L, et al: Cerebrospinal fluid biomarkers to stratify injury severity and predict outcome in human traumatic spinal cord injury. J Neurotrauma 34:567-580, 2017

93. Kwon BK, Tetzlaff W, Grauer JN, Beiner J, Vaccaro AR: Pathophysiology and pharmacologic treatment of acute spinal cord injury. Spine J 4:451-464, 2004

94. Lalu MM, Sullivan KJ, Mei SH, Moher D, Straus A, Fergusson DA, et al: Evaluating mesenchymal stem cell therapy for sepsis with preclinical meta-analyses prior to initiating a first-in-human trial. eLife 5:5, 2016

95. Lang-Lazdunski L, Heurteaux C, Vaillant N, Widmann C, Lazdunski M: Riluzole prevents ischemic spinal cord injury caused by aortic crossclamping. J Thorac Cardiovasc Surg 117:881-889, 1999

96. LaPlaca MC, Simon CM, Prado GR, Cullen DK: CNS injury biomechanics and experimental models. Prog Brain Res 161:13-26, 2007

97. Law S, Chaudhuri S: Mesenchymal stem cell and regenera- tive medicine: regeneration versus immunomodulatory challenges. Am J Stem Cells 2:22-38, 2013

98. Lawrence DG, Kuypers HG: The functional organization of the motor system in the monkey. I. The effects of bilateral pyramidal lesions. Brain 91:1-14, 1968

99. Lee BB, Cripps RA, Fitzharris M, Wing PC: The global map for traumatic spinal cord injury epidemiology: update 2011, global incidence rate. Spinal Cord 52:110-116, 2014

100. Lee SM, Yune TY, Kim SJ, Park DW, Lee YK, Kim YC, et al: Minocycline reduces cell death and improves functional recovery after traumatic spinal cord injury in the rat. $\mathbf{J}$ Neurotrauma 20:1017-1027, 2003

101. Lee YS, Hsiao I, Lin VW: Peripheral nerve grafts and aFGF restore partial hindlimb function in adult paraplegic rats. J Neurotrauma 19:1203-1216, 2002

102. Lenehan B, Fisher CG, Vaccaro A, Fehlings M, Aarabi B, Dvorak MF: The urgency of surgical decompression in acute central cord injuries with spondylosis and without instability. Spine (Phila Pa 1976) 35 (21 Suppl):S180 S186, 2010

103. Lenehan B, Street J, Kwon BK, Noonan V, Zhang H, Fisher CG, et al: The epidemiology of traumatic spinal cord injury in British Columbia, Canada. Spine (Phila Pa 1976) 37:321-329, 2012

104. Levi AD, Casella G, Green BA, Dietrich WD, Vanni S, Jagid J, et al: Clinical outcomes using modest intravascular hypothermia after acute cervical spinal cord injury. Neurosurgery 66:670-677, 2010

105. Levi AD, Okonkwo DO, Park P, Jenkins AL III, Kurpad SN, Parr AM, et al: Emerging safety of intramedullary transplantation of human neural stem cells in chronic cervical and thoracic spinal cord injury. Neurosurgery 82:562575,2018

106. Levi AD, Tator $\mathrm{CH}$, Bunge RP: Clinical syndromes associated with disproportionate weakness of the upper versus the lower extremities after cervical spinal cord injury. Neurosurgery 38:179-183, 1996

107. Levi L, Wolf A, Belzberg H: Hemodynamic parameters in patients with acute cervical cord trauma: description, intervention, and prediction of outcome. Neurosurgery 33:1007-1017, 1993

108. Levinson BLJ, Chou H, Maiman D: SUN13837 in treatment of acute spinal cord injury, the ASCENT-ASCI Study. Clin Neurol Neurosci 2:1-8, 2018

109. Li L, Adnan H, Xu B, Wang J, Wang C, Li F, et al: Effects of transplantation of olfactory ensheathing cells in chronic spinal cord injury: a systematic review and meta-analysis. Eur Spine J 24:919-930, 2015

110. Li S, Mealing GA, Morley P, Stys PK: Novel injury mechanism in anoxia and trauma of spinal cord white matter: glutamate release via reverse $\mathrm{Na}+$-dependent glutamate transport. J Neurosci 19:RC16, 1999

111. Li S, Stys PK: Mechanisms of ionotropic glutamate receptor-mediated excitotoxicity in isolated spinal cord white matter. J Neurosci 20:1190-1198, 2000

112. Li Y, Field PM, Raisman G: Repair of adult rat corticospinal tract by transplants of olfactory ensheathing cells. Science 277:2000-2002, 1997

113. Liu J, Chen P, Wang Q, Chen Y, Yu H, Ma J, et al: Meta analysis of olfactory ensheathing cell transplantation promoting functional recovery of motor nerves in rats with complete spinal cord transection. Neural Regen Res 9:1850-1858, 2014

114. Liu M, Wu W, Li H, Li S, Huang LT, Yang YQ, et al: Necroptosis, a novel type of programmed cell death, contributes to early neural cells damage after spinal cord injury in adult mice. J Spinal Cord Med 38:745-753, 2015

115. Liu Y, Ye H, Satkunendrarajah K, Yao GS, Bayon Y, Fehlings MG: A self-assembling peptide reduces glial scar- 
ring, attenuates post-traumatic inflammation and promotes neurological recovery following spinal cord injury. Acta Biomater 9:8075-8088, 2013

116. Lord-Fontaine S, Yang F, Diep Q, Dergham P, Munzer S, Tremblay P, et al: Local inhibition of Rho signaling by cellpermeable recombinant protein BA-210 prevents secondary damage and promotes functional recovery following acute spinal cord injury. J Neurotrauma 25:1309-1322, 2008

117. Maroon JC, Abla AA, Wilberger JI, Bailes JE, Sternau LL: Central cord syndrome. Clin Neurosurg 37:612-621, 1991

118. Martin AR, De Leener B, Cohen-Adad J, Cadotte DW, Kalsi-Ryan S, Lange SF, et al: Clinically feasible microstructural MRI to quantify cervical spinal cord tissue injury using DTI, MT, and T2*-weighted imaging: assessment of normative data and reliability. AJNR Am J Neuroradiol 38: $1257-1265,2017$

119. Martin AR, De Leener B, Cohen-Adad J, Cadotte DW, Kalsi-Ryan S, Lange SF, et al: A novel MRI biomarker of spinal cord white matter injury: T2*-weighted white matter to gray matter signal intensity ratio. AJNR Am J Neuroradiol 38: 1266-1273, 2017

120. McCaughey EJ, Purcell M, McLean AN, Fraser MH, Bewick A, Borotkanics RJ, et al: Changing demographics of spinal cord injury over a 20 -year period: a longitudinal population-based study in Scotland. Spinal Cord 54:270-276, 2016

121. Milhorat TH, Capocelli AL Jr, Anzil AP, Kotzen RM, Milhorat RH: Pathological basis of spinal cord cavitation in syringomyelia: analysis of 105 autopsy cases. J Neurosurg 82:802-812, 1995

122. Miller RG, Mitchell JD, Moore DH: Riluzole for amyotrophic lateral sclerosis (ALS)/motor neuron disease (MND). Cochrane Database Syst Rev (3):CD001447, 2012

123. Moreau-Fauvarque C, Kumanogoh A, Camand E, Jaillard C, Barbin G, Boquet I, et al: The transmembrane semaphorin Sema4D/CD100, an inhibitor of axonal growth, is expressed on oligodendrocytes and upregulated after CNS lesion. J Neurosci 23:9229-9239, 2003

124. Morshead CM, Reynolds BA, Craig CG, McBurney MW, Staines WA, Morassutti D, et al: Neural stem cells in the adult mammalian forebrain: a relatively quiescent subpopulation of subependymal cells. Neuron 13:1071-1082, 1994

125. Mothe AJ, Tam RY, Zahir T, Tator CH, Shoichet MS: Repair of the injured spinal cord by transplantation of neural stem cells in a hyaluronan-based hydrogel. Biomaterials 34:3775-3783, 2013

126. Mothe AJ, Zahir T, Santaguida C, Cook D, Tator CH: Neural stem/progenitor cells from the adult human spinal cord are multipotent and self-renewing and differentiate after transplantation. PLoS One 6:e27079, 2011

127. Nagoshi N, Khazaei M, Ahlfors JE, Ahuja CS, Nori S, Wang J, et al: Human spinal oligodendrogenic neural progenitor cells promote functional recovery after spinal cord injury by axonal remyelination and tissue sparing. Stem Cells Transl Med [epub ahead of print], 2018

128. National Spinal Cord Injury Statistical Center: Spinal Cord Injury Facts and Figures at a Glance. Birmingham, AL: NSCISC, 2018 (https://www.nscisc.uab.edu/Public/ Facts\%20and\%20Figures\%20-\%202018.pdf) [Accessed October 8, 2018].

129. Neuhuber B, Timothy Himes B, Shumsky JS, Gallo G, Fischer I: Axon growth and recovery of function supported by human bone marrow stromal cells in the injured spinal cord exhibit donor variations. Brain Res 1035:73-85, 2005

130. Norenberg MD, Smith J, Marcillo A: The pathology of human spinal cord injury: defining the problems. J Neurotrauma 21:429-440, 2004

131. Nori S, Ahuja CS, Fehlings MG: Translational advances in the management of acute spinal cord injury: What is new? What is hot? Neurosurgery 64 (CN_suppl_1):119-128, 2017

132. Pakulska MM, Tator CH, Shoichet MS: Local delivery of chondroitinase $\mathrm{ABC}$ with or without stromal cell-derived factor $1 \alpha$ promotes functional repair in the injured rat spinal cord. Biomaterials 134: 13-21, 2017

133. Palmer TD, Takahashi J, Gage FH: The adult rat hippocampus contains primordial neural stem cells. Mol Cell Neurosci 8:389-404, 1997

134. Pappas CT, Gibson AR, Sonntag VK: Decussation of hindlimb and fore-limb fibers in the monkey corticospinal tract: relevance to cruciate paralysis. J Neurosurg 75:935-940, 1991

135. Parr AM, Kulbatski I, Zahir T, Wang X, Yue C, Keating A, et al: Transplanted adult spinal cord-derived neural stem/ progenitor cells promote early functional recovery after rat spinal cord injury. Neuroscience 155:760-770, 2008

136. Pineau I, Lacroix S: Proinflammatory cytokine synthesis in the injured mouse spinal cord: multiphasic expression pattern and identification of the cell types involved. J Comp Neurol 500:267-285, 2007

137. Pouw MH, van Middendorp JJ, van Kampen A, Curt A, van de Meent H, Hosman AJ: Diagnostic criteria of traumatic central cord syndrome. Part 3: descriptive analyses of neurological and functional outcomes in a prospective cohort of traumatic motor incomplete tetraplegics. Spinal Cord 49:614-622, 2011

138. Pritchard CD, Slotkin JR, Yu D, Dai H, Lawrence MS, Bronson RT, et al: Establishing a model spinal cord injury in the African green monkey for the preclinical evaluation of biodegradable polymer scaffolds seeded with human neural stem cells. J Neurosci Methods 188:258-269, 2010

139. Quencer RM, Bunge RP, Egnor M, Green BA, Puckett W, Naidich TP, et al: Acute traumatic central cord syndrome: MRI-pathological correlations. Neuroradiology 34:85-94, 1992

140. Ramer LM, Au E, Richter MW, Liu J, Tetzlaff W, Roskams AJ: Peripheral olfactory ensheathing cells reduce scar and cavity formation and promote regeneration after spinal cord injury. J Comp Neurol 473:1-15, 2004

141. Roth EJ, Lawler MH, Yarkony GM: Traumatic central cord syndrome: clinical features and functional outcomes. Arch Phys Med Rehabil 71:18-23, 1990

142. Scher AT: Hyperextension trauma in the elderly: an easily overlooked spinal injury. J Trauma 23:1066-1068, 1983

143. Schneider RC, Cherry G, Pantek H: The syndrome of acute central cervical spinal cord injury; with special reference to the mechanisms involved in hyperextension injuries of cervical spine. J Neurosurg 11:546-577, 1954

144. Schneider RC, Crosby EC, Russo RH, Gosch HH: Chapter 32. Traumatic spinal cord syndromes and their management. Clin Neurosurg 20:424-492, 1973

145. Schwartz G, Fehlings MG: Evaluation of the neuroprotective effects of sodium channel blockers after spinal cord injury: improved behavioral and neuroanatomical recovery with riluzole. J Neurosurg 94 (2 Suppl):245-256, 2001

146. Schwartz G, Fehlings MG: Secondary injury mechanisms of spinal cord trauma: a novel therapeutic approach for the management of secondary pathophysiology with the sodium channel blocker riluzole. Prog Brain Res 137:177-190, 2002

147. Schwartzman RJ: A behavioral analysis of complete unilateral section of the pyramidal tract at the medullary level in Macaca mulatta. Ann Neurol 4:234-244, 1978

148. Sekhon LH, Fehlings MG: Epidemiology, demographics, and pathophysiology of acute spinal cord injury. Spine (Phila Pa 1976) 26 (24 Suppl):S2-S12, 2001

149. Sekiya I, Larson BL, Smith JR, Pochampally R, Cui JG, 
Prockop DJ: Expansion of human adult stem cells from bone marrow stroma: conditions that maximize the yields of early progenitors and evaluate their quality. Stem Cells 20:530-541, 2002

150. Sharp J, Frame J, Siegenthaler M, Nistor G, Keirstead HS: Human embryonic stem cell-derived oligodendrocyte progenitor cell transplants improve recovery after cervical spinal cord injury. Stem Cells 28:152-163, 2010

151. Siddiqui AM, Khazaei M, Fehlings MG: Translating mechanisms of neuroprotection, regeneration, and repair to treatment of spinal cord injury. Prog Brain Res 218:15-54, 2015

152. Silva NA, Cooke MJ, Tam RY, Sousa N, Salgado AJ, Reis RL, et al: The effects of peptide modified gellan gum and olfactory ensheathing glia cells on neural stem/progenitor cell fate. Biomaterials 33:6345-6354, 2012

153. Simard JM, Tsymbalyuk O, Keledjian K, Ivanov A, Ivanova S, Gerzanich V: Comparative effects of glibenclamide and riluzole in a rat model of severe cervical spinal cord injury. Exp Neurol 233:566-574, 2012

154. Singh A, Tetreault L, Kalsi-Ryan S, Nouri A, Fehlings MG: Global prevalence and incidence of traumatic spinal cord injury. Clin Epidemiol 6:309-331, 2014

155. Sparling JS, Bretzner F, Biernaskie J, Assinck P, Jiang $\mathrm{Y}$, Arisato $\mathrm{H}$, et al: Schwann cells generated from neonatal skin-derived precursors or neonatal peripheral nerve improve functional recovery after acute transplantation into the partially injured cervical spinal cord of the rat. $\mathbf{J}$ Neurosci 35:6714-6730, 2015

156. Stys PK: General mechanisms of axonal damage and its prevention. J Neurol Sci 233:3-13, 2005

157. Suzuki H, Ahuja CS, Salewski RP, Li L, Satkunendrarajah $\mathrm{K}$, Nagoshi N, et al: Neural stem cell mediated recovery is enhanced by Chondroitinase $\mathrm{ABC}$ pretreatment in chronic cervical spinal cord injury. PLoS One 12:e0182339, 2017

158. Tafida MA, Wagatsuma Y, Ma E, Mizutani T, Abe T: Descriptive epidemiology of traumatic spinal injury in Japan. J Orthop Sci 23:273-276, 2018

159. Tator $\mathrm{CH}$ : Update on the pathophysiology and pathology of acute spinal cord injury. Brain Pathol 5:407-413, 1995

160. Tator $\mathrm{CH}$, Fehlings MG: Review of the secondary injury theory of acute spinal cord trauma with emphasis on vascular mechanisms. J Neurosurg 75:15-26, 1991

161. Tator CH, Fehlings MG, Thorpe K, Taylor W: Current use and timing of spinal surgery for management of acute spinal surgery for management of acute spinal cord injury in North America: results of a retrospective multicenter study. $\mathbf{J}$ Neurosurg 91 (1 Suppl): 12-18, 1999

162. Teng YD, Lavik EB, Qu X, Park KI, Ourednik J, Zurakowski D, et al: Functional recovery following traumatic spinal cord injury mediated by a unique polymer scaffold seeded with neural stem cells. Proc Natl Acad Sci U S A 99:3024-3029, 2002

163. Theodore N, Hlubek R, Danielson J, Neff K, Vaickus L, Ulich TR, et al: First human implantation of a bioresorbable polymer scaffold for acute traumatic spinal cord injury: a clinical pilot study for safety and feasibility. Neurosurgery 79:E305-E312, 2016

164. Thompson C, Mutch J, Parent S, Mac-Thiong JM: The changing demographics of traumatic spinal cord injury: An 11 -year study of 831 patients. J Spinal Cord Med 38:214223,2015

165. Thrasher TA, Flett HM, Popovic MR: Gait training regimen for incomplete spinal cord injury using functional electrical stimulation. Spinal Cord 44:357-361, 2006

166. Ulndreaj A, Chio JC, Ahuja CS, Fehlings MG: Modulating the immune response in spinal cord injury. Expert Rev Neurother 16:1127-1129, 2016

167. Vale FL, Burns J, Jackson AB, Hadley MN: Combined medical and surgical treatment after acute spinal cord injury: results of a prospective pilot study to assess the merits of aggressive medical resuscitation and blood pressure management. J Neurosurg 87:239-246, 1997

168. Van Den Berg M, Castellote JM, Mahillo-Fernandez I, de Pedro-Cuesta J: Incidence of traumatic spinal cord injury in Aragón, Spain (1972-2008). J Neurotrauma 28:469-477, 2011

169. van den Berg ME, Castellote JM, Mahillo-Fernandez I, de Pedro-Cuesta J: Incidence of spinal cord injury worldwide: a systematic review. Neuroepidemiology 34:184-192, 2010

170. van Middendorp JJ, Hosman AJ, Doi SA: The effects of the timing of spinal surgery after traumatic spinal cord injury: a systematic review and meta-analysis. J Neurotrauma 30:1781-1794, 2013

171. van Middendorp JJ, Pouw MH, Hayes KC, Williams R, Chhabra HS, Putz C, et al: Diagnostic criteria of traumatic central cord syndrome. Part 2: a questionnaire survey among spine specialists. Spinal Cord 48:657-663, 2010

172. Wang Y, Wang H, Tao Y, Zhang S, Wang J, Feng X: Necroptosis inhibitor necrostatin-1 promotes cell protection and physiological function in traumatic spinal cord injury. Neuroscience 266:91-101, 2014

173. Watzlawick R, Rind J, Sena ES, Brommer B, Zhang T, Kopp MA, et al: Olfactory ensheathing cell transplantation in experimental spinal cord injury: effect size and reporting bias of 62 experimental treatments: a systematic review and meta-analysis. PLoS Biol 14:e1002468, 2016

174. Wells JE, Hurlbert RJ, Fehlings MG, Yong VW: Neuroprotection by minocycline facilitates significant recovery from spinal cord injury in mice. Brain 126:1628-1637, 2003

175. Wiliams RR, Bunge MB: Schwann cell transplantation: a repair strategy for spinal cord injury? Prog Brain Res 201:295-312, 2012

176. Wilson JR, Singh A, Craven C, Verrier MC, Drew B, Ahn $\mathrm{H}$, et al: Early versus late surgery for traumatic spinal cord injury: the results of a prospective Canadian cohort study. Spinal Cord 50:840-843, 2012

177. Wilson JR, Tetreault LA, Kwon BK, Arnold PM, Mroz TE, Shaffrey C, et al: Timing of decompression in patients with acute spinal cord injury: a systematic review. Global Spine J 7 (3 Suppl):95S-115S, 2017

178. Windus LC, Lineburg KE, Scott SE, Claxton C, MackaySim A, Key B, et al: Lamellipodia mediate the heterogeneity of central olfactory ensheathing cell interactions. Cell Mol Life Sci 67:1735-1750, 2010

179. Wu JC, Huang WC, Chen YC, Tu TH, Tsai YA, Huang SF, et al: Acidic fibroblast growth factor for repair of human spinal cord injury: a clinical trial. J Neurosurg Spine 15:216-227, 2011

180. Wu JC, Huang WC, Tsai YA, Chen YC, Cheng H: Nerve repair using acidic fibroblast growth factor in human cervical spinal cord injury: a preliminary phase I clinical study. J Neurosurg Spine 8:208-214, 2008

181. Wu Y, Satkunendrarajah K, Fehlings MG: Riluzole improves outcome following ischemia-reperfusion injury to the spinal cord by preventing delayed paraplegia. Neuroscience 265:302-312, 2014

182. Wu Y, Satkunendrarajah K, Teng Y, Chow DS, Buttigieg J, Fehlings MG: Delayed post-injury administration of riluzole is neuroprotective in a preclinical rodent model of cervical spinal cord injury. J Neurotrauma 30:441-452, 2013

183. Wu Y, Satkundrarajah K, Teng Y, Chow DS, Fehlings MG: Evaluation of the sodium-glutamate blocker riluzole in a preclinical model of ervical spinal cord injury. Evid Based Spine Care J 1:71-72, 2010

184. Wyndaele M, Wyndaele JJ: Incidence, prevalence and epidemiology of spinal cord injury: what learns a worldwide literature survey? Spinal Cord 44:523-529, 2006 
185. Yan X, Cen Y, Wang Q: Mesenchymal stem cells alleviate experimental rheumatoid arthritis through microRNA-regulated IкB expression. Sci Rep 6:28915, 2016

186. Yousefifard M, Rahimi-Movaghar V, Nasirinezhad F, Baikpour M, Safari S, Saadat S, et al: Neural stem/progenitor cell transplantation for spinal cord injury treatment; A systematic review and meta-analysis. Neuroscience 322:377-397, 2016

187. Yrjänheikki J, Keinänen R, Pellikka M, Hökfelt T, Koistinaho J: Tetracyclines inhibit microglial activation and are neuroprotective in global brain ischemia. Proc Natl Acad Sci U S A 95: 15769-15774, 1998

188. Zhang J, Chen H, Duan Z, Chen K, Liu Z, Zhang L, et al: The effects of co-transplantation of olfactory ensheathing cells and Schwann cells on local inflammation environment in the contused spinal cord of rats. Mol Neurobiol 54:943953,2017

189. Zweckberger K, Ahuja CS, Liu Y, Wang J, Fehlings MG: Self-assembling peptides optimize the post-traumatic milieu and synergistically enhance the effects of neural stem cell therapy after cervical spinal cord injury. Acta Biomater 42:77-89, 2016

\section{Disclosures}

Dr. Fehlings reports a consultant relationship with Fortuna Fix.

\section{Author Contributions}

Conception and design: all authors. Acquisition of data: Badhiwala, Ahuja. Analysis and interpretation of data: Badhiwala, Ahuja. Drafting the article: Badhiwala, Ahuja. Critically revising the article: all authors. Reviewed submitted version of manuscript: all authors. Approved the final version of the manuscript on behalf of all authors: Fehlings. Administrative/technical/material support: Fehlings. Study supervision: Fehlings.

\section{Correspondence}

Michael G. Fehlings: Toronto Western Hospital, Toronto, ON, Canada.michael.fehlings@uhn.ca. 